\title{
Immune suppression or enhancement by CD137 T cell costimulation during acute viral infection is time dependent
}

\author{
Benyue Zhang, ${ }^{1}$ Charles H. Maris, ${ }^{1}$ Juergen Foell, ${ }^{2}$ Jason Whitmire, ${ }^{3}$ Liguo Niu, ${ }^{1}$ Jing Song, ${ }^{1}$ \\ Byoung S. Kwon, ${ }^{4}$ Anthony T. Vella, ${ }^{5}$ Rafi Ahmed, ${ }^{1}$ Joshy Jacob, ${ }^{1}$ and Robert S. Mittler ${ }^{1}$

\begin{abstract}
${ }^{1}$ Emory Vaccine Center, Emory University School of Medicine, Atlanta, Georgia, USA. ${ }^{2}$ Department of Hematology and Oncology, Martin Luther University, Halle-Wittenberg, Germany. ${ }^{3}$ Department of Immunology, The Scripps Research Institute, La Jolla, California, USA.

${ }^{4}$ Department of Interdisciplinary Oncology and Immunomodulation Research Center, University of Ulsan, Ulsan, Republic of Korea. ${ }^{5}$ Department of Immunology, University of Connecticut Health Center, Farmington, Connecticut, USA.
\end{abstract}

\begin{abstract}
CD137 is expressed on activated $\mathrm{T}$ cells and ligands to this costimulatory molecule have clinical potential for amplifying CD8 $\mathrm{T}$ cell immunity to tumors and viruses, while suppressing CD4 autoimmune $\mathrm{T}$ cell responses. To understand the basis for this dichotomy in $\mathrm{T}$ cell function, CD4 and CD8 antiviral immunity was measured in lymphocytic choriomeningitis virus (LCMV) Armstrong- or A/PR8/34 influenza-infected mice injected with anti-CD137 mAbs. We found that the timing of administration of anti-CD137 mAbs profoundly altered the nature of the antiviral immune response during acute infection. Antiviral immunity progressed normally for the first $\mathbf{7 2}$ hours when the $\mathrm{mAb}$ was administered early in infection before undergoing complete collapse by day 8 postinfection. Anti-CD137-injected LCMV-infected mice became tolerant to, and persistently infected with, LCMV Armstrong. Elevated levels of IL-10 early in the response was key to the loss of CD4 ${ }^{+} \mathrm{T}$ cells, whereas $\mathrm{CD8}^{+} \mathrm{T}$ cell deletion was dependent on a prolonged TNF- $\alpha$ response, IL-10, and upregulation of Fas. Blocking IL-10 function rescued CD4 antiviral immunity but not $\mathrm{CD8}^{+} \mathrm{T}$ cell deletion. Anti-CD137 treatment given beyond 72 hours after infection significantly enhanced antiviral immunity. Mice treated with anti-CD137 $\mathrm{mAb} 1$ day before infection with A/PR8/34 virus experienced $80 \%$ mortality compared with $40 \%$ mortality of controls. When treatment was delayed until day 1 postinfection, $100 \%$ of the infected mice survived. These data show that anti-CD137 mAbs can induce $T$ cell activation-induced cell death or enhance antiviral immunity depending on the timing of treatment, which may be important for vaccine development.
\end{abstract}

\section{Introduction}

CD137, a TNF receptor family member, is an activation-inducible T cell costimulatory receptor $(1,2)$ that is expressed on cells of the innate and adaptive immune system (reviewed in ref. 3). CD137 ligands induce $\mathrm{T}$ cell proliferation and cytokine production in vitro (4-8), whereas CD137 ligands confer potent costimulatory effects upon $\mathrm{CD}^{+} \mathrm{T}$ cells in vivo $(9,10)$. Although CD137 crosslinking costimulates $\mathrm{CD}^{+} \mathrm{T}$ cells to proliferate in vitro, remarkably, it suppresses the development of T cell-dependent humoral immunity in vivo (11). Both attributes have made this reagent attractive for therapeutic use in treating cancer and autoimmune disease, and it is currently being evaluated for use as an adjuvant in vaccine design (12). Herein we assess the effect of altering the timing of anti-CD137 treatment during viral infection and in so doing reconcile the dichotomy between CD137-induced CD8 ${ }^{+}$ $\mathrm{T}$ cell activation and $\mathrm{CD} 4^{+} \mathrm{T}$ cell suppression. We found that virusspecific $\mathrm{CD}^{+}$and $\mathrm{CD}^{+} \mathrm{T}$ cell proliferation proceeds normally over the first 3 days of infection. By day 8 postinfection (P.I.), large numbers of virus-specific $\mathrm{CD} 4^{+}$and $\mathrm{CD}^{+} \mathrm{T}$ cells were deleted, thus leading to the loss of humoral and $\mathrm{T}$ cell-mediated antiviral immune responses. Anti-CD137-injected lymphocytic choriomeningitis virus-infected (LCMV-infected) mice rapidly produced high

Nonstandard abbreviations used: ICS, intercellular cytokine staining; LCMV, lymphocytic choriomeningitis virus; P.I., postinfection.

Conflict of interest: The authors have declared that no conflict of interest exists. Citation for this article: J. Clin. Invest. 117:3029-3041 (2007). doi:10.1172/JCI32426. levels of IL-10 and developed sustained TNF- $\alpha$ production during the late stages of infection, leading to Fas expression on $\mathrm{CD}^{+}$ $\mathrm{T}$ cells. Blockade of IL-10 signaling fully rescued virus-specific $\mathrm{CD} 4^{+} \mathrm{T}$ cells but minimally affected $\mathrm{CD} 8^{+} \mathrm{T}$ cell function and survival. In T cells from virus-infected anti-CD137-injected IL-10 ${ }^{-/}$ mice treated with anti-TNF- $\alpha$ mAbs, Fas was downregulated, $\mathrm{CD}^{+} \mathrm{T}$ cells were not deleted, and antiviral immunity remained intact. When anti-CD137 treatment was withheld until day 4 P.I., the magnitude of antiviral immunity was significantly enhanced, demonstrating that anti-CD $137 \mathrm{mAb}$ treatment could induce in a time-dependent manner 2 diametrically opposed outcomes.

\section{Results}

Anti-CD137 mAb treatment during LCMV infection suppressed antiviral $T$ cell immunity. CD137 ligands deliver costimulatory signals to $\mathrm{CD}^{+} \mathrm{T}$ cells in vivo and paradoxically suppress $\mathrm{CD}^{+} \mathrm{T}$ helper cells despite being costimulatory for both in vitro $(11,13,14)$. This has raised the question of whether CD137 signaling differentially regulates $\mathrm{CD}^{+}$and $\mathrm{CD}^{+} \mathrm{T}$ cell effector function. We addressed this question in 2 viral infection models because its resolution has important ramifications for the therapeutic use of CD137 ligands. LCMV Armstrong induces an acute infection in mice that is rapidly cleared while eliciting long-lasting immunity. Antiviral immunity was measured in LCMV-infected mice given $200 \mu \mathrm{g}$ of agonist anti-CD $137 \mathrm{mAbs}$ or rat IgG on day 1 P.I. Consistent with earlier reports $(11,13-15)$, we found that this treatment markedly suppressed $\mathrm{CD}^{+} \mathrm{T}$ cells as measured by T cell-dependent LCMV-spe- 

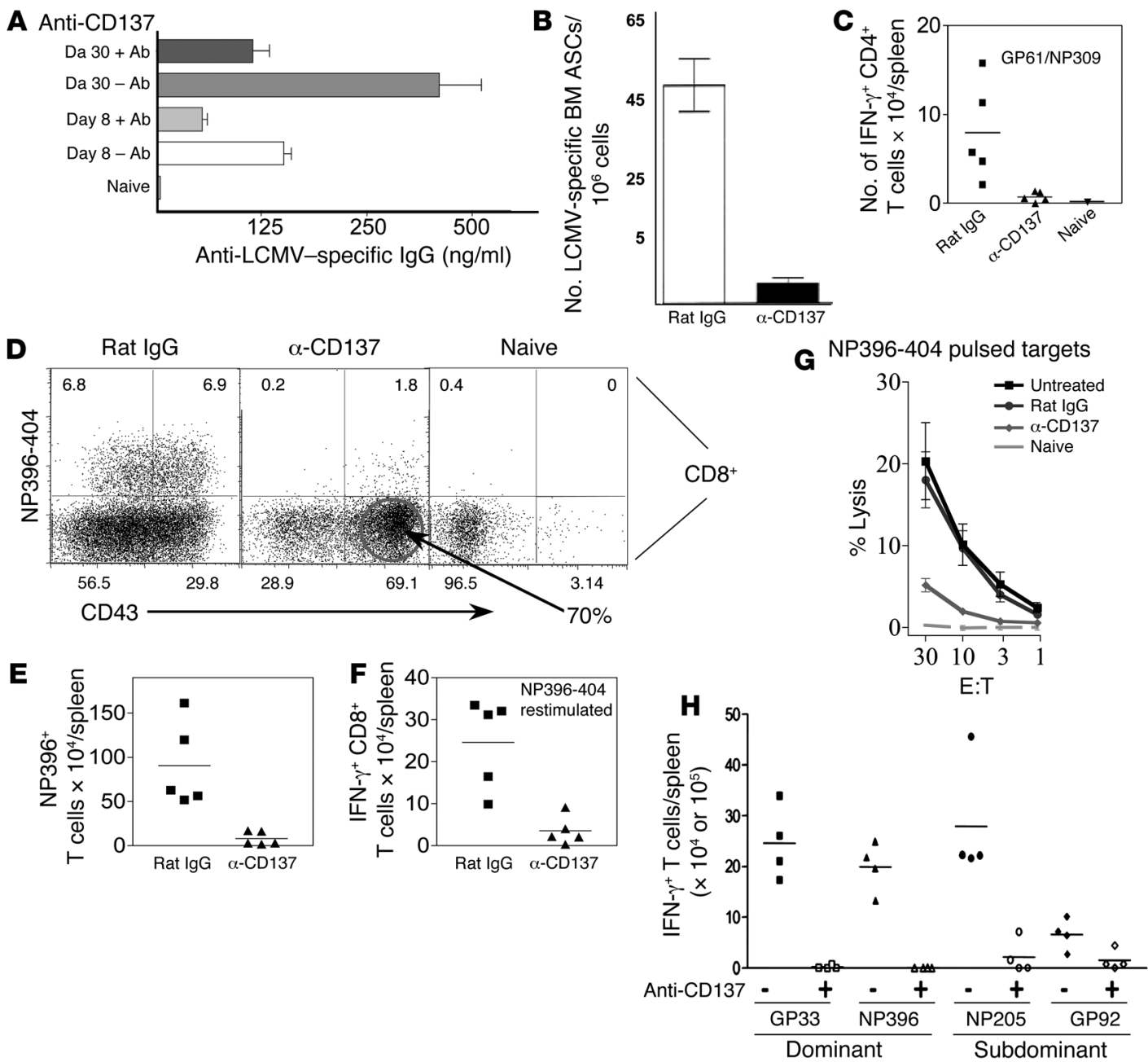

Figure 1

Anti-CD137 mAbs suppress antiviral immunity. An acute viral infection was generated in C57BL/6 mice by injecting $2 \times 10^{5}$ PFU LCMV Armstrong i.p. followed by injection of $200 \mu \mathrm{g} \alpha$-CD137 (clone 3H3) or rat IgG by i.p. on day 1 P.I. (A) Reduction in virus-specific T cell-dependent humoral immunity on days 8 and 30 P.I. (B) Marked reduction in the number of virus-specific antibody-secreting cells in bone marrow at day 30 P.I. (C) $\mathrm{CD}^{+} \mathrm{T}$ cells were unable to produce IFN- $\gamma$ following in vitro peptide restimulation with CD4-restricted immunodominant LCMV-derived peptides on day 8 P.I. (D) On day 8 P.I. antiviral CD8 ${ }^{+}$T cell expansion was determined by D'NP396-404 tetramer staining and CD43 upregulation on virus-activated T cells. (E) Absolute numbers of NP396-404+ CD8 ${ }^{+}$T cells were enumerated following FACS analysis of tetramer-stained T cells. (F) IFN- $\gamma$ staining was measured following in vitro NP396-404 peptide restimulation and ICS with a FITC-conjugated anti-IFN- $\gamma$ mAb. (G) CTL responses against NP396-404 peptide-pulsed MC57 cells were measured ex vivo from naive mice (lines), LCMV-infected anti-CD137-injected mice (diamonds), LCMV-infected rat IgG-injected mice (circles), and LCMV-infected untreated mice (squares). E:T, effector to target ratio. Data are from 1 representative experiment of 3. (H) LCMV-specific CD8 ${ }^{+} \mathrm{T}$ cell responses to immunodominant epitopes were $10^{5} \mathrm{IFN}-\gamma^{+} \mathrm{T}$ cells/spleen, subdominant epitopes were $10^{4} \mathrm{IFN}-\gamma^{+} \mathrm{T}$ cells/spleen on day $30 \mathrm{P}$.I. by measuring IFN- $\gamma$ production in response to in vitro peptide restimulation, ICS, and FACS analysis.

cific IgG (Figure 1A), enumerating LCMV-specific antibody-secreting cells in the BM (Figure 1B) and measuring IFN- $\gamma^{+} \mathrm{CD}^{+} \mathrm{T}$ cells (Figure 1C). In dose response studies we found that $30 \mu \mathrm{g}$ of $\mathrm{mAb}$ was sufficient to induce suppression when given on day 1 P.I. (data not shown). That anti-CD137 costimulates $\mathrm{CD}^{+} \mathrm{T}$ cells has been widely reported in the literature, and at no time has it been shown to be inhibitory. Remarkably, in this study we found complete suppression of antiviral CD8 ${ }^{+} \mathrm{T}$ cell responses. We found a marked reduction in tetramer-positive $\mathrm{CD}^{+} \mathrm{T}$ cells (Figure $1 \mathrm{D}$ ), reduction in numbers of virus-specific $\mathrm{CD}^{+} \mathrm{T}$ cells (Figure $1 \mathrm{E}$ ), absence of IFN- $\gamma^{+} \mathrm{CD}^{+} \mathrm{T}$ cells (Figure $1 \mathrm{~F}$ ), and failure to induce antiviral $\mathrm{CTL}$ responses (Figure 1G). Although the $\mathrm{CD}^{+} \mathrm{T}$ cell response was almost completely suppressed, approximately $70 \%$ of splenic $\mathrm{CD}^{+} \mathrm{T}$ cells had upregulated CD43 expression, an indicator of activation (Figure 1D, middle panel), indicating that non-antigen-specific $\mathrm{CD}^{+} \mathrm{T}$ cells were being activated during this process. It is not known precisely how these $\mathrm{T}$ cells undergo activation or what the consequences of this event are. However, we have found that polyclonal $\mathrm{T}$ cell activation occurs in naive mice injected with anti-CD137 mAbs and that this event is dependent upon TNF- $\alpha$ production (16). We next tested whether suppression was linked to specific CD8 LCMV epitopes, but found that this was not the case, as dominant and subdominant immune responses were fully suppressed (Figure 1H). Suppression was not unique to the $3 \mathrm{H} 3$ 

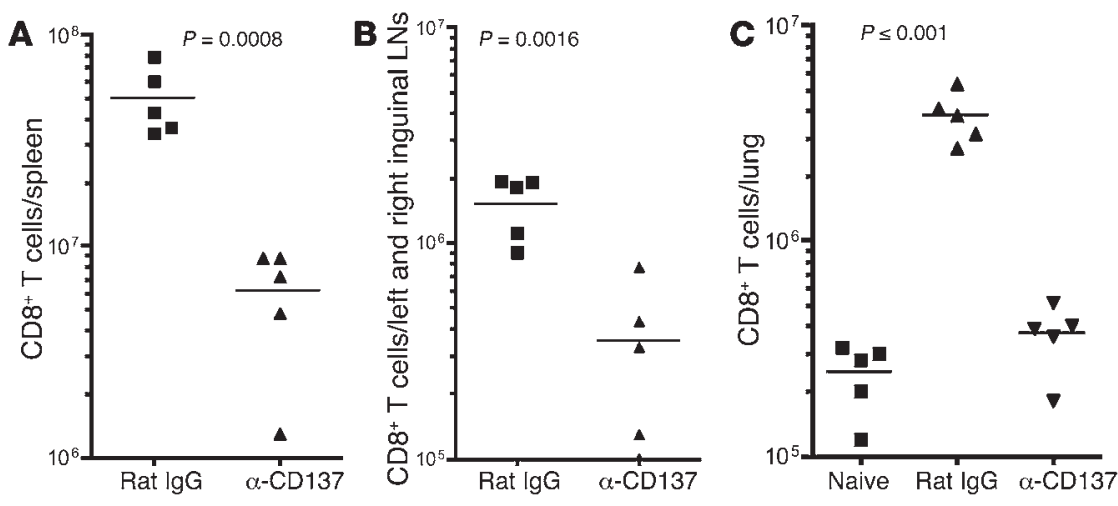

\section{Figure 2}

Loss of $\mathrm{CD}^{+} \mathrm{T}$ cells in anti-CD137-injected virus-infected mice. C57BL/6 mice were infected by i.p. injection of $2 \times 10^{5}$ PFU LCMV Armstrong. The following day, mice were injected i.p. with $200 \mu \mathrm{g}$ of either anti-CD137 or rat lgG. Mice were euthanized on day 8 P.I. and CD8 ${ }^{+}$ T cells enumerated by FACS analysis in (A) spleen, (B) pooled left and right inguinal $\mathrm{LNs}$, and $(\mathbf{C})$ lung.
$\mathrm{mAb}$, the epitope it recognizes, or its isotype, as other anti-CD137 mAbs differing in these characteristics produced equivalent responses (data not shown). Induction of suppression was independent of anti-CD137-mediated blocking of CD137 interaction with its ligand, as suppression occurred in LCMV-infected 4-1BB ligand-deficient mice (data not shown). The absence of antiviral $\mathrm{T}$ cell responses in anti-CD137-injected mice was evident in the spleen, LN, lung, and liver of treated mice (Figure 2 and data not shown). If T cell activation had occurred as suggested in Figure 1D, then $\mathrm{T}$ cell deletion must have followed. To verify this we followed virus-induced $\mathrm{CD}^{+}$and $\mathrm{CD}^{+} \mathrm{T}$ cell phenotypic conversion from a naive $\mathrm{CD} 44^{\mathrm{lo}} \mathrm{CD} 62 \mathrm{~L}^{+}$phenotype to a CD44hi $\mathrm{CD} 62 \mathrm{~L}^{\mathrm{lo} /-}$ memory phenotype. On day 4 P.I. anti-CD137-injected mice had fewer $\mathrm{CD}_{4}{ }^{\mathrm{hi}} \mathrm{CD} 62 \mathrm{~L}^{\mathrm{lo} /-}$ splenic $\mathrm{CD} 4^{+} \mathrm{T}$ cells than the rat $\mathrm{IgG}-$ injected control mice (Figure 3A). Consistent with elevated expression of CD43 on $\mathrm{CD}^{+} \mathrm{T}$ cells (Figure 1D), when examined on day 4 P.I. we observed increased frequencies (data not shown) and absolute cell numbers of CD44hi $C D 62 \mathrm{~L}^{\mathrm{lo} /-} \mathrm{T}$ cells in anti-CD137-injected mice (Figure 3B). However, by day 8 P.I. the numbers of activated memory-like $\mathrm{CD}^{+}$and $\mathrm{CD}^{+} \mathrm{T}$ cells in anti-CD137-injected mice had significantly decreased (Figure $3, \mathrm{C}$ and D). $\mathrm{CD} 4^{+}$and $\mathrm{CD}^{+}$ $\mathrm{T}$ cell proliferation was measured by $1 \times 10^{6}$ CFSE-labeled CD8 ${ }^{+}$ TCR-transgenic P14 T cells and an equivalent number of CFSElabeled CD4+ TCR-transgenic SMARTA T cells adoptively transferred into CD45.1 congenic recipients. The mice were infected and injected the following day with $200 \mu \mathrm{g}$ of anti-CD137 or rat IgG. On days 2-4 P.I. mice were euthanized and spleen cells were gated on CD45.2, CD4, and CD8 expression and CFSE dilution (Figure 3E). By days 2 and 3 P.I., P14 T cells and SMARTA CD4+ $\mathrm{T}$ cells proliferated similarly regardless of treatment. By day 4 P.I. $\mathrm{CD}^{+}$and $\mathrm{CD}^{+} \mathrm{T}$ cells in all mice had diluted their CFSE content beyond detection (data not shown). Next, CFSE-labeled P14 and SMARTA $T$ cell recipients were injected on day 1 P.I. with antiCD137 or rat IgG injection and euthanized at varying times and the number of splenic CFSE ${ }^{+} \mathrm{CD} 45.2^{+} \mathrm{CD}^{+}$and $\mathrm{CD}^{+} \mathrm{T}$ cells was determined. By day 4 P.I. there was a marked loss of P14 T cells in the spleens of anti-CD137-injected mice (Figure 3F). Based on Annexin V and 7AAD staining (see Anti-CD137 induced IL-10 production), it seems that this reduction in P14 T cell numbers in the spleens of anti-CD137-injected mice may represent trafficking rather than deletion.

Anti-CD137 induced persistent viral infection. To quantitate the immune response to LCMV in anti-CD137-treated mice, we used MHC class I tetramers specific for immunodominant and subdominant epitopes. We were able to identify small numbers of refracto- ry GP33-41-specific CD8 ${ }^{+} \mathrm{T}$ cells through 100 days P.I., but none were specific for NP396-404, a finding reminiscent of persistent clone 13 infection. We concluded that the ablated immunodominant response was not due to disrupted dominance hierarchies, as responses to the subdominant epitopes were similarly lacking (Figure $1 \mathrm{H}$ ), and anti-CD137-mediated immune suppression was not global because CD8 ${ }^{+} \mathrm{T}$ cells from LCMV-infected anti-CD137injected mice produced IFN- $\gamma$ after stimulation with PMA and ionomycin (data not shown). Furthermore, LCMV-infected mice given anti-CD137 on day 1 P.I. were viremic at 8 days P.I. and remained viremic through 100 days P.I., the last time point tested (Figure 4). When anti-CD 137 treatment was delayed until day 3 P.I., the mice generated antiviral immunity that resulted in eradication of the virus (Figure 4), leading us to conclude that induction of CD137mediated signaling during the initiation of an LCMV infection incapacitated the host's immune system and left them tolerant to, and persistently infected with, LCMV Armstrong.

Kinetics of anti-CD137-induced immunosuppression. Anti-CD137induced $\mathrm{CD}^{+} \mathrm{T}$ cell deletion was unexpected and, to our knowledge, novel and was contrary to all previous studies of CD137mediated CD8 immune regulation. Therefore we studied the kinetics of anti-CD137 treatment over a wider range of time points. When mice were injected once with anti-CD137 on day 1 P.I. or day 2 P.I., immunosuppression was observed in LCMVinfected mice, and when antibody was administered beyond this point, the mice developed enhanced antiviral immunity to LCMV (Figure 5, A and B).

Anti-CD137 targets T cells. Because DCs and NK cells express CD137, and given the kinetics of anti-CD137-induced immunosuppression, we hypothesized that anti-CD137 mAbs might be targeting either the function of DCs or NK cells, an event that leads to incomplete $\mathrm{T}$ cell activation. However, when adoptive CD137-/DC transfer or NK depletion studies were carried out, this proved

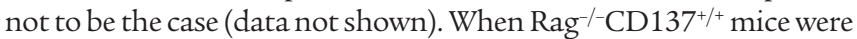
reconstituted with $4-20 \times 10^{6} \mathrm{CD} 137^{-/-} \mathrm{CD}^{+} \mathrm{T}$ cells, infected, and treated with anti-CD137, they generated normal frequencies and absolute numbers of GP33-41 tetramer-positive and IFN- $\gamma$-producing $\mathrm{CD}^{+} \mathrm{T}$ cells (Figure 6). In contrast, when wild-type $\mathrm{CD} 137^{+/+}$ $\mathrm{C} 57 \mathrm{BL} / 6 \mathrm{CD} 8^{+} \mathrm{T}$ cells were transferred into these mice and the mice were infected with LCMV and treated with anti-CD137 on day 1 P.I., antiviral immunity was completely suppressed (Figure 6).

Anti-CD137 induced IL-10 production. Type I IFNs play a critical role in the clearance of LCMV Armstrong infections, and blocking their function results in a failure to eliminate virus and therefore we measured type I IFN production (17). However, no change was 

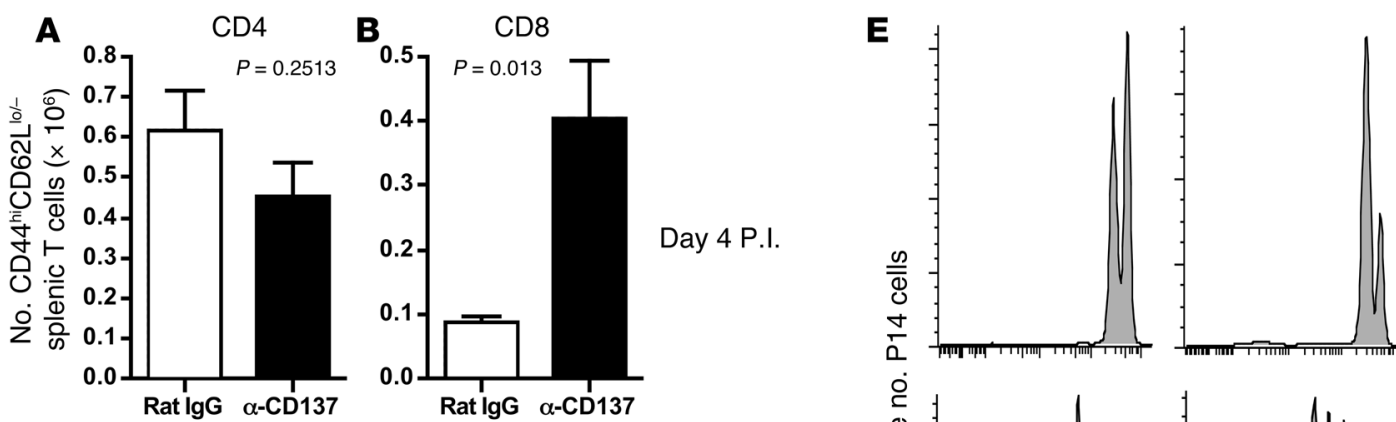

Day 2 P.I.

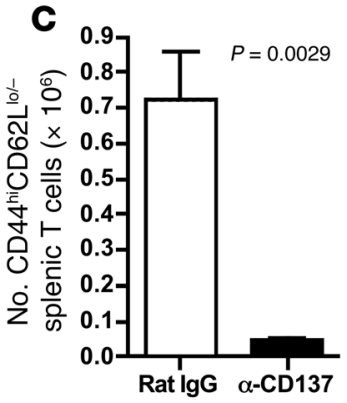

D
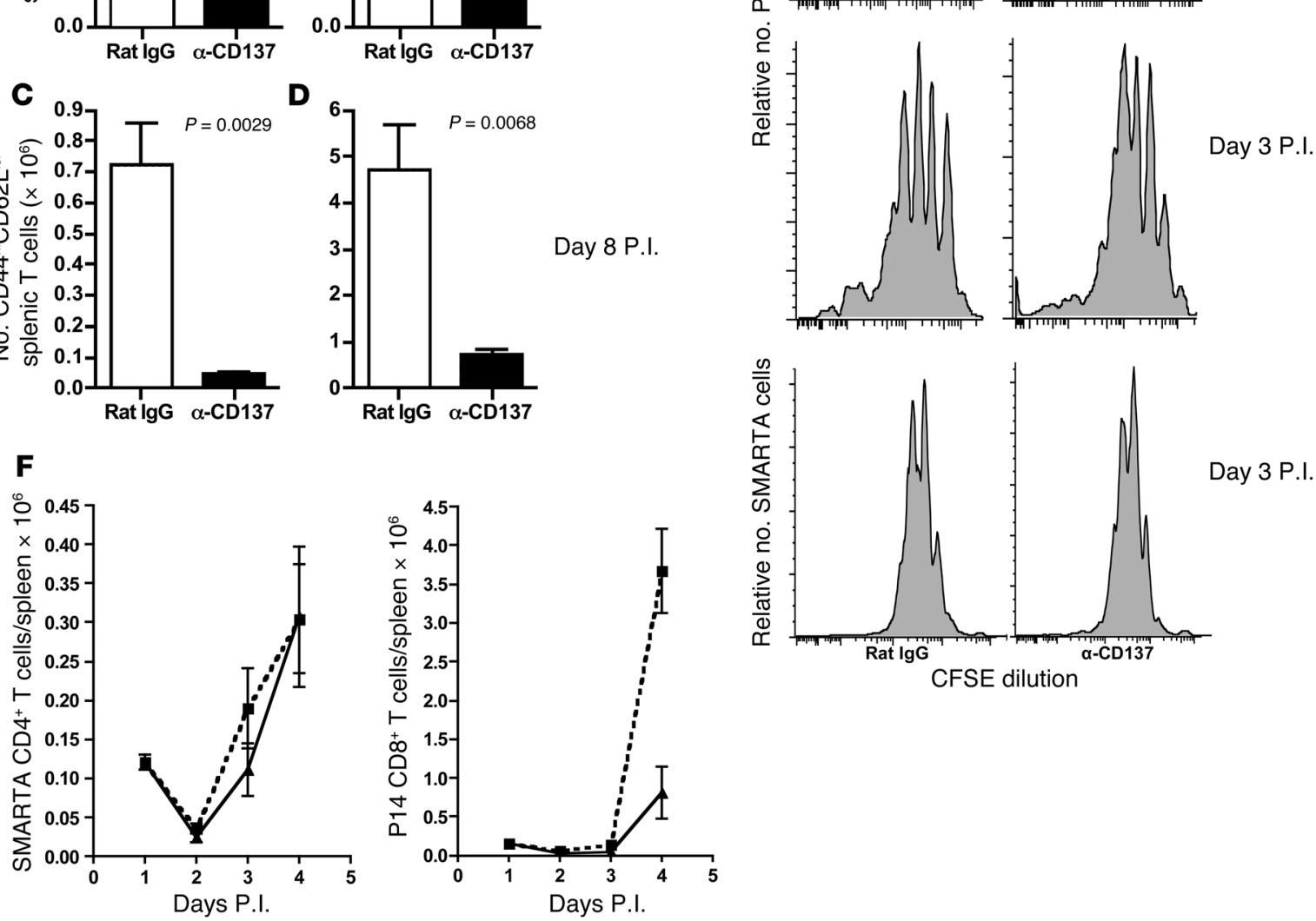

Figure 3

Anti-CD137 induced CD8 ${ }^{+}$T cell activation. Spleens from groups of 5 LCMV-infected anti-CD137- or rat lgG-injected mice were collected on day

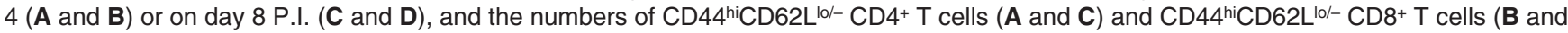
D) were counted following FACS analysis. (E) Groups of 4 C57BL/6 CD45.1 PepBoy mice were injected i.v. with $1 \times 10^{6}$ CFSE-labeled C57BL/6 CD45.2+ P14 LCMV TCR-transgenic CD8 ${ }^{+}$T cells and an equal number of CFSE-labeled C57BL/6 CD45.2+ SMARTA LCMV TCR-transgenic CD4 ${ }^{+} T$ cells. The mice were then infected i.p. with $2 \times 10^{5}$ PFU LCMV Armstrong and injected i.p. 24 hours later with $200 \mu \mathrm{g}$ anti-CD137 or rat IgG. On days 2 and 3 P.I. the mice were euthanized and splenic CD45.2CD8+ T cells and CD45.2CD4+ T cells were gated during FACS analysis and their CFSE content measured. (F) Spleens from groups of 4 C57BL/6 mice reconstituted with CFSE-labeled CD4 ${ }^{+}$and CD8 ${ }^{+}$TCR-transgenic T cells infected with LCMV Armstrong and injected with $200 \mathrm{ug}$ of either rat IgG (dotted lines) or anti-CD137 (solid lines) were collected on the indicated days, stained with fluorochrome-conjugated mAbs specific for CD45.2, CD4, and CD8, and analyzed by FACS and trypan blue exclusion to determine the number of viable cells of each lineage.

noted between controls and anti-CD137-treated mice (data not shown). We next measured IL-10 levels in these mice because IL-10 negatively regulates Th1 immune responses (reviewed in ref. 18) and, in the case of persistent LCMV infections, blockade of IL-10 function restored antiviral immunity in these mice $(19,20)$. We found a rapid increase in serum IL-10 levels in LCMV-infected mice injected day 1 P.I. with anti-CD137. IL-10 was detected by day 2 P.I. and peaked by days 3-4 of infection in anti-CD137-injected mice (Figure 7A). IL-10 was not detected in LCMV-infected control mice until day 6 P.I., and then it was at much lower levels (Figure 7A). IL-10 was also not produced in uninfected anti-CD137-injected mice (data not shown). One mechanism of action for IL-10 is the deletion of virus-specific $\mathrm{CD}^{+} \mathrm{T}$ cells $(21,22)$. However, we found that cell death was minimal in $\mathrm{CD}^{+}$and $\mathrm{CD}^{+} \mathrm{T}$ cells by day 4 P.I., consistent with $\mathrm{T}$ cell expansion (Figure $3 \mathrm{E}$ ), but by day 8 P.I. we observed significant apoptosis in both cell types (Figure 7B). Thus IL-10 may program virus-specific $\mathrm{CD}^{+} \mathrm{T}$ cell death $(23)$ in anti-CD137-injected LCMV-infected mice. The role of IL-10 was further assessed because $\mathrm{CD}^{+} \mathrm{T}$ cells were also deleted, making it unclear to what extent the induction of IL-10 and deletion of $\mathrm{CD}^{+} \mathrm{T}$ cells contributed to anti-CD137-induced immune suppression. We determined whether anti-IL-10 receptor blocking 


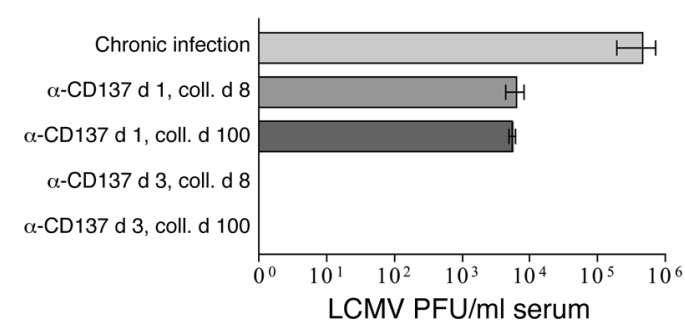

Figure 4

Anti-CD137-injected LCMV-infected mice remain persistently viremic. Groups of C57BL/6 mice $(n=5)$ were infected with LCMV Armstrong and given anti-CD137 mAbs on either day 1 or day 3 P.I. Sera were collected (coll.) on day 8 and day 100 P.I., and plaque assays were performed to detect viable virus. Chronic viral infections, included for comparison to anti-CD137-treated mice, were initiated by injecting $2 \times 10^{6}$ PFU LCMV clone 13 i.v. into mice that had also received 500 ug GK1.5 (anti-CD4) 1 day before infection. Sera from chronically infected mice were collected on day 30 P.I. The limit of detection for this assay was $500 \mathrm{PFU} / \mathrm{ml}$.

would prevent anti-CD137-induced suppression. This treatment had a significant effect on restoring the frequency and absolute numbers of CD $44^{\mathrm{hi}} \mathrm{CD} 62 \mathrm{~L}^{\mathrm{lo} /-} \mathrm{CD} 4^{+} \mathrm{T}$ cells, and this was also seen in IL-10-deficient mice where deletion of CD44hi $\mathrm{CD} 62 \mathrm{~L}^{\mathrm{lo} /-} \mathrm{CD} 8^{+}$ $\mathrm{T}$ cells were still present (Figure 7C and data not shown). Thus IL-10 alone is responsible for the loss of $\mathrm{CD}^{+} \mathrm{T}$ cells in antiCD137-injected LCMV-infected mice. However, unlike LCMV clone 13 infection, IL-10 receptor blockade in anti-CD137-injected LCMV Armstrong-infected mice was insufficient for rescue of $\mathrm{CD}^{+} \mathrm{T}$ cell deletion and restoration of antiviral immunity.

TNF- $\alpha$ - and Fas-induced T cell death. We measured TNF- $\alpha$ levels in virus-infected mice because TNF- $\alpha$ can induce cell death and because we have previously found elevated TNF- $\alpha$ levels in anti-CD137-injected mice (our unpublished observations). Upon gross examination we found that spleens from infected anti-CD137-injected mice were smaller than those obtained from day 8 virus-infected controls (85-100 mg versus $160-230$ $\mathrm{mg}$ ). We also observed a 5 - to 10 -fold reduction in the number of CD44hi CD62 $\mathrm{L}^{\mathrm{lo} /-} \mathrm{T}$ cells in anti-CD137-treated infected mice (Figure 3, C and D) and found substantial losses in the numbers of $\mathrm{CD} 44^{\mathrm{hi}} \mathrm{CD} 62 \mathrm{~L}^{\mathrm{lo} /-} \mathrm{CD} 8{ }^{+} \mathrm{T}$ cells in the spleens of anti-CD137injected virus-infected IL-10-/- mice (data not shown), suggesting that while IL-10 is not the major cause for the loss of CD8 ${ }^{+} \mathrm{T}$ cells, it nonetheless appears to be a contributing factor. Because $T$ cell deletion can occur through TNF receptor 1-mediated and/or Fasmediated apoptosis and TNF- $\alpha$ is upregulated in T cells during the late stages of LCMV infection (24), both were measured following infection. LCMV-infected mice had elevated levels of TNF- $\alpha$ in their serum by day 5 P.I. that subsided $24-48$ hours later. In contrast, TNF- $\alpha$ levels in anti-CD137-injected virus-infected mice remained high through day 12 P.I., the last time point examined (Figure 8A). Supporting a role for TNF- $\alpha$ in the induction of suppression, we found that anti-CD137-induced suppression to LCMV was partially blunted in $\mathrm{TNF}^{-/-}$mice (Figure 8, B and C), where the mean frequency of GP33-41 tetramer-positive splenic $\mathrm{T}$ cells was approximately $2 \%$ compared with $5.5 \%$ for controls. In contrast, we found the mean frequency of GP33-41 tetramerpositive splenic T cells to be $0.85 \%$ in LCMV-infected anti-CD 137 injected C57BL/6 mice compared with 7.4\% in LCMV-infected rat
IgG-injected C57BL/ 6 controls. Furthermore, these changes can be seen in total numbers of GP33-41 tetramer-positive and IFN- $\gamma$ positive $\mathrm{CD}^{+} \mathrm{T}$ cells (Table 1 ). Thus not only is suppression blunted in $\mathrm{TNF}^{-/-}$mice, but also the response to LCMV infection was somewhat lower than that seen in C57BL/ 6 mice. TNF- $\alpha$ has a well documented role in inducing $T$ cell apoptosis regulated by RelA and NF- $\mathrm{KB}(25,26)$, and it is known to induce Fas expression $(27,28)$. Thus IL-10 and TNF- $\alpha$ appear to function in tandem to induce $\mathrm{CD}^{+}$and $\mathrm{CD}^{+} \mathrm{T}$ cell apoptosis, respectively. We assessed whether $\mathrm{T}$ cells in LCMV-infected mice expressed Fas and found that $12 \%$ of $\mathrm{CD}^{+}$memory $\mathrm{T}$ cells from rat IgG-injected mice expressed Fas on their surface, whereas this increased to $87 \%$ in anti-CD137-injected mice (Figure 9A). To determine whether Fas was required for $\mathrm{CD}^{+} \mathrm{T}$ cell deletion, $\mathrm{Fas}^{-/-}$mice were infected with LCMV and injected with anti-CD137 or rat IgG on day 1 P.I. Both groups of mice were able to generate $\mathrm{CD} 8^{+} \mathrm{T}$ cell responses to LCMV epitopes with kinetics observed in wild-type mice (data not shown). However, whereas $35 \%$ of splenic $\mathrm{CD}^{+} \mathrm{T}$ cells from anti-CD137-treated virus-infected C57BL/ 6 mice were preapoptotic, apoptotic, or necrotic, only $8 \%$ of $\mathrm{CD}^{+} \mathrm{T}$ cells from the spleens of $\mathrm{Fas}^{-/-}$mice fell into these categories, a frequency identical to that observed in C57BL/6 virus-infected mice injected with rat IgG (Figure 9B). A similar but less dramatic result was seen in $\mathrm{CD}^{+} \mathrm{T}$ cells (Figure 9C). The reduction in the frequencies of apoptotic cells in $\mathrm{Fas}^{-/}$mice was mirrored by restoration of spleen cell numbers (Figure 9D), and tetramer-positive or IFN- $\gamma$-producing $\mathrm{CD}^{+} \mathrm{T}$ cells (Figure 9E) in infected and treated $\mathrm{Fas}^{-/-}$mice versus $\mathrm{C} 57 \mathrm{BL} / 6$ mice. We conclude that $\mathrm{CD} 4^{+} \mathrm{T}$ cell deletion is mediated by IL-10 signaling, whereas $\mathrm{CD}^{+} \mathrm{T}$ cell deletion appears to be in part dependent on IL-10 signaling and TNF- $\alpha$-induced, Fas-dependent apoptosis.

Antiviral immunity in anti-TNF- $\alpha$-injected anti-CD137-treated IL-10-/- mice. When anti-CD137-treated LCMV-infected IL-10-/mice were given neutralizing anti-TNF- $\alpha \mathrm{mAb}$, we observed no loss in the numbers of splenic CD $44^{\mathrm{hi}} \mathrm{CD} 62 \mathrm{~L}^{\mathrm{lo} /-} \mathrm{CD} 8^{+} \mathrm{T}$ cells or LN T cells (Figure 10, A and B). We tested whether anti-TNF- $\alpha$ treatment of infected anti-CD137-injected IL-10/- mice would lower Fas expression and found this to be the case (Figure 10C).

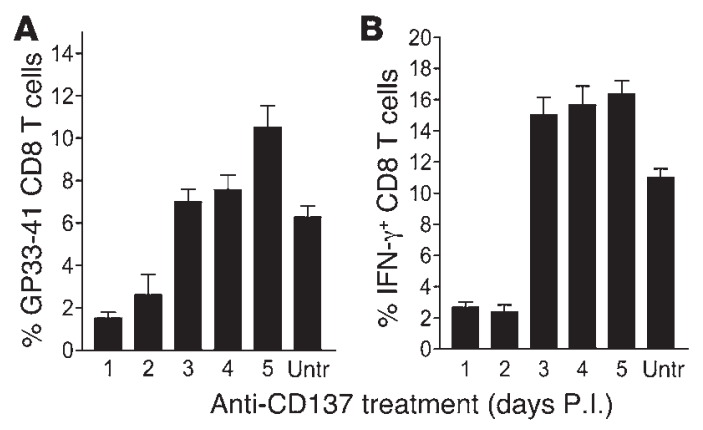

\section{Figure 5}

Kinetics of anti-CD137-induced immune suppression. Groups of C57BL/6 mice $(n=5)$ were infected i.p. with $2 \times 10^{5}$ PFU LCMV Armstrong. One group of mice was then injected once with anti-CD137 i.p. 24 hours P.I. A second group was injected 1 day later and so on through day 5 P.I. On day 8 P.I. all groups were euthanized. (A) The percentage of GP33-41 tetramer-positive CD8+ splenic T cells was determined by FACS analysis. (B) Following in vitro GP33-41 peptide restimulation for 5 hours, the percentage of IFN- $\gamma-$ producing CD8 ${ }^{+}$ T cells was measured by ICS and FACS analysis. Untr, untreated. 

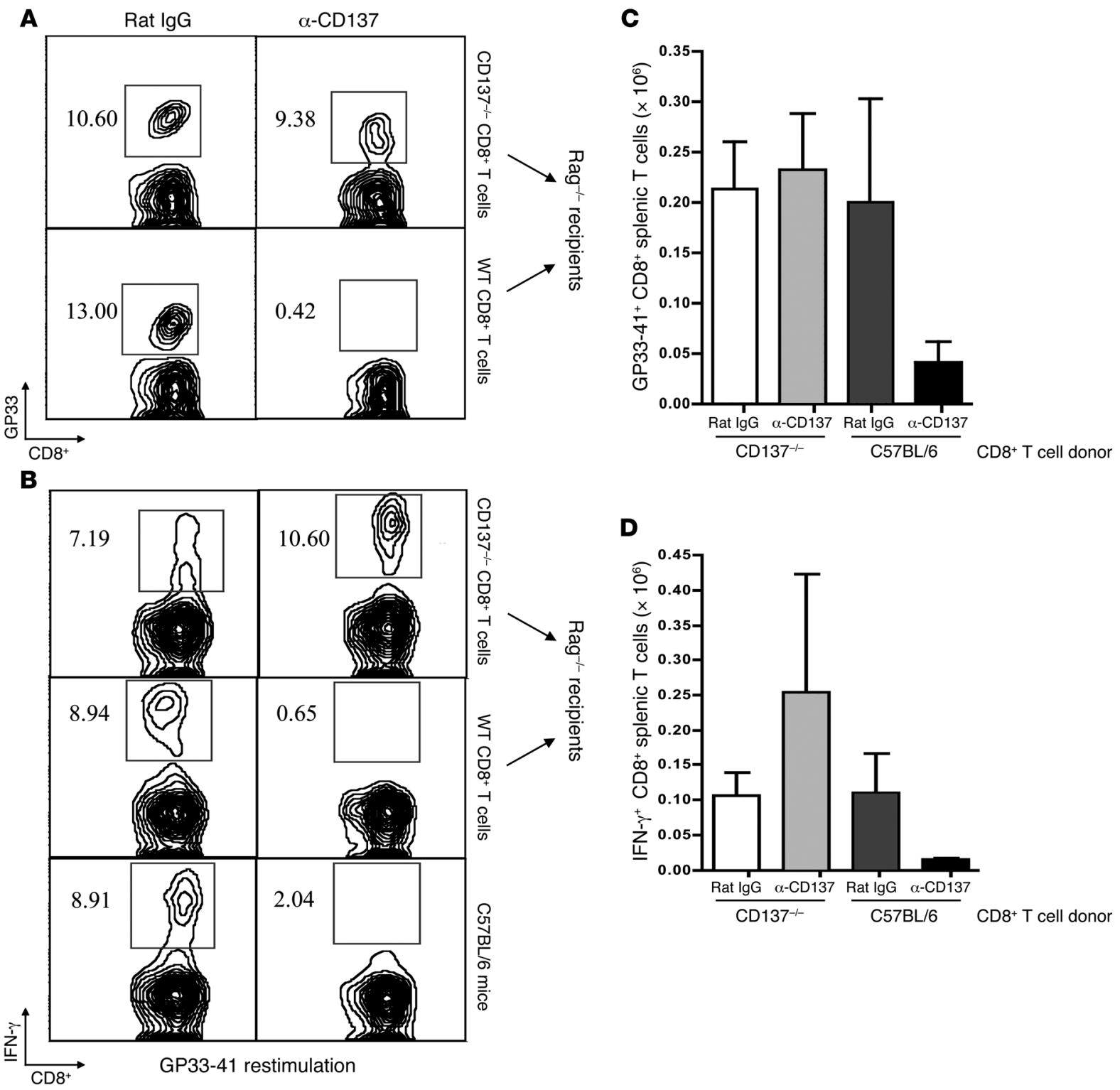

Figure 6

Anti-CD137 directly induces anergy in T cells. CD137-deficient or C57BL/6 splenic CD8 ${ }^{+}$T cells $\left(4-20 \times 10^{6}\right)$ were adoptively transferred by tail vein injection into $\mathrm{Rag}^{-/}$mice. The following day the mice were infected by i.p. injection with $2 \times 10^{5}$ PFU LCMV Armstrong. On day 1 P.I., 1 group of mice was injected with $200 \mu \mathrm{g}$ anti-CD137, and a second group was injected with an equal amount of rat IgG. On day 8 P.I., the mice were euthanized and the frequencies (A) and total number (C) of GP33-41 tetramer-positive CD8+ T cells were determined by FACS analysis. Likewise, the frequencies (B) and absolute numbers (D) of IFN- $\gamma$-producing CD8 ${ }^{+}$T cells were determined after 5 hours of in vitro GP33-41 restimulation, followed by cell permeablization and ICS with a FITC-conjugated anti-IFN- $\gamma$ mAb. The numbers in the boxes indicate the percentage of GP33-41+ CD8 $8^{+} \mathrm{T}$ cells (A) and the percentage of IFN- $\gamma^{+}$CD8+ T cells (B). Representative data from 1 of 5 mice are shown from 3 experiments.

We questioned whether anti-TNF- $\alpha$ would rescue antiviral immunity, and here too we found this to be the case (Figure 10, D-F). Thus anti-CD137-mediated signaling alters cytokine profiles in LCMV-infected mice. During the initial stage of infection, high levels of IL-10 are produced, and this has a deleterious effect on $\mathrm{CD}^{+} \mathrm{T}$ cell survival. Midway through the infection (day 5), TNF- $\alpha$ production was briefly upregulated in virus-infected mice, whereas anti-CD137-injected mice maintained high levels of TNF- $\alpha$ in their serum for at least 6 days and concurrently expressed Fas on their T cells. In the absence of IL-10 signaling, and together with neutralizing anti-TNF- $\alpha$ mAbs, antiviral immunity could be established in anti-CD137-injected mice.

Anti-CD137 induced suppression in influenza-infected mice. To measure anti-CD137-induced suppression in another viral infection, we assessed the ability of anti-CD $137 \mathrm{mAbs}$ to suppress immunity to influenza. C57BL/6 mice were intranasally infected with $6 \mathrm{HA}$ units of influenza virus $\mathrm{A} / \mathrm{PR} 8 / 34$ strain and injected with anti$\mathrm{CD} 137$ or rat IgG at various time points prior to or after infection. 


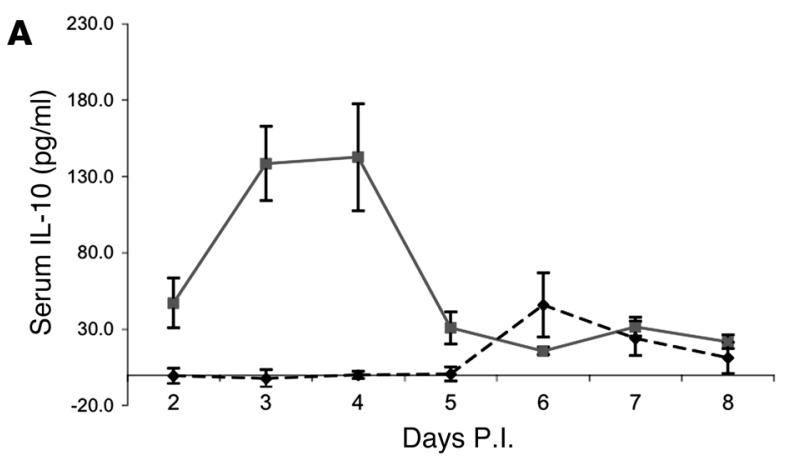

B
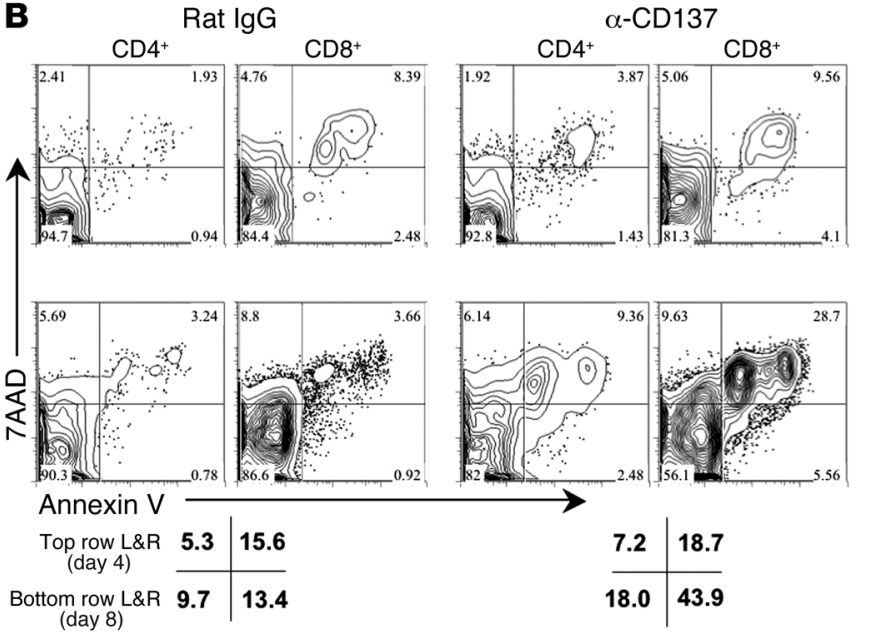

c

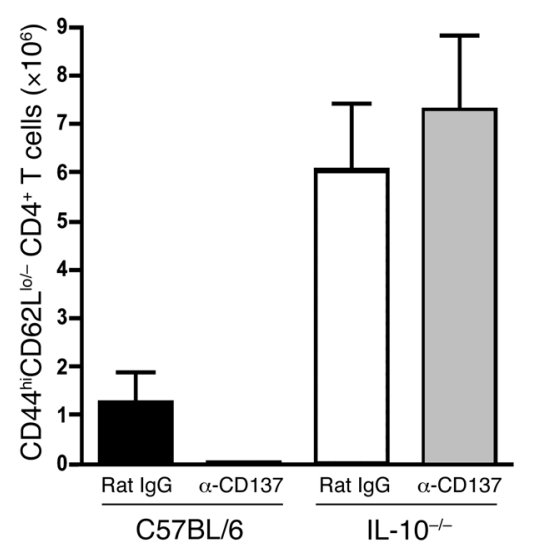

Progression and severity of infection was measured by weight loss and survival. Although the kinetics of anti-CD137 treatment differed from that observed in LCMV infection (day -1 versus day 1 ), the consequences were similar. We found that $80 \%$ of the mice injected with anti-CD137 one day prior to A/PR8/34 infection lost over $25 \%$ of their body weight and succumbed to infection (Figure $10 \mathrm{G})$. In contrast, $40 \%$ of rat IgG-injected A/PR8/34-infected mice succumbed to the infection (Figure $10 \mathrm{H}$ ). Remarkably, despite an initial loss in weight, $100 \%$ of the A/PR8/34-infected mice given anti-CD137 on day 1 P.I. $(n=5)$ survived the infection (Figure 10I). Thus similar to that observed in LCMV-infected mice, anti-CD137 either induced suppression or enhanced immunity depending on the timing of its administration. We do not understand the reason(s) for the shift in kinetics of anti-CD137-induced immune suppression observed between the 2 infections nor do we under-

\section{Figure 7}

IL-10 and T cell deletion. (A) Serum IL-10 levels in LCMV Armstronginfected mice treated with anti-CD137 (solid line) or rat IgG (dotted line) were measured by ELISA over the 8-day course of the infection. Staggered groups $(n=5)$ of mice were bled ( $100 \mu \mathrm{l}$ whole blood) twice on overlapping days to avoid stressing the mice. The data are typical of 3 experiments. (B) Groups of 5 mice were infected with LCMV Armstrong and injected the following day with anti-CD137 or rat IgG. On days 4 and 8 P.I., the mice were euthanized and the frequencies of preapoptotic, apoptotic, and necrotic splenic CD4+ and CD8 ${ }^{+} \mathrm{T}$ cells determined by $7 A A D$ and Annexin $V$ staining. The sum of the frequencies of dead and dying cells consisted of the frequencies of cells falling in the 2 right quadrants + the upper left quadrant of each of the 4 contour plots shown, and their sums are shown in the cross-hair figure under each of the 2 sets of contour plots. (C) CD4 $4^{+} \mathrm{T}$ cell loss is absent in LCMV Armstrong-infected anti-CD137-injected IL-10-deficient mice. Mice were infected with LCMV and injected with anti-CD137 or rat IgG as described above. The number of CD44 ${ }^{\text {hi }} \mathrm{CD} 2 \mathrm{~L}^{\mathrm{Io} /-} \mathrm{CD} 4^{+}$ splenic T cells was measured by FACS on day 8 P.I.

stand the molecular basis underlying these opposing responses, but these questions are under investigation.

\section{Discussion}

CD137 ligands are in Phase I clinical trials to treat melanoma patients, and their use will be evaluated for treating autoimmune disease and as adjuvants for vaccines. Understanding the consequences of using these reagents in vivo is therefore of considerable importance. Anti-CD137 mAbs costimulate T cells in vitro. However, in vivo use of CD137 ligands in a variety of models, and under different experimental conditions, have shown that only $\mathrm{CD}^{+} \mathrm{T}$ cell function is amplified or sustained as a consequence of treatment (4), in part due to upregulation of antiapoptotic genes $(8,29)$. In contrast, $\mathrm{CD}^{+} \mathrm{T}$ cell function is suppressed by anti-CD137 mAbs in normal mice (11) and following treatment of autoimmune mice $(14,15,30)$, leaving unresolved the question of whether $\mathrm{CD}^{+}$and $\mathrm{CD} 8^{+} \mathrm{T}$ cells are differentially regulated by CD137. We addressed this question in this study using antiCD137-injected LCMV Armstrong-infected mice in order to track virus-specific $\mathrm{CD}^{+}$and $\mathrm{CD}^{+} \mathrm{T}$ cell responses in individual mice. Based on previously published data, we expected to find $\mathrm{CD}^{+}$ $\mathrm{T}$ cell responses to be suppressed and $\mathrm{CD}^{+}$responses to be amplified. Remarkably, we found that $\mathrm{CD}^{+}$and $\mathrm{CD} 4^{+} \mathrm{T}$ cell responses to LCMV infection were, for all intents and purposes, completely suppressed. Induction of immune suppression was dependent on the timing of anti-CD137 treatment. When anti-CD137 was injected prior to infection (data not shown) or within 48 hours P.I., antiviral immunity in all lymphoid compartments and organs was suppressed. LCMV Armstrong-infected anti-CD137-treated mice became tolerant to and persistently infected with this acute strain of LCMV that is typically cleared within 2 weeks of infection. When treatment was delayed beyond 48 hours P.I., the T cell immune response was significantly enhanced, $\mathrm{T}$ cell-dependent humoral immunity was normal, and the mice cleared their infection with normal kinetics.

Our studies describe what we believe to be a new and unexpected role for CD137 signaling during an immune response. First, engagement of CD137 on T cells can significantly impair immune responses of $\mathrm{CD}^{+}$and $\mathrm{CD}^{+} \mathrm{T}$ cell responses; the sole difference between inducing immune suppression and enhancing antiviral immune responses in these models was found to be the timing of 

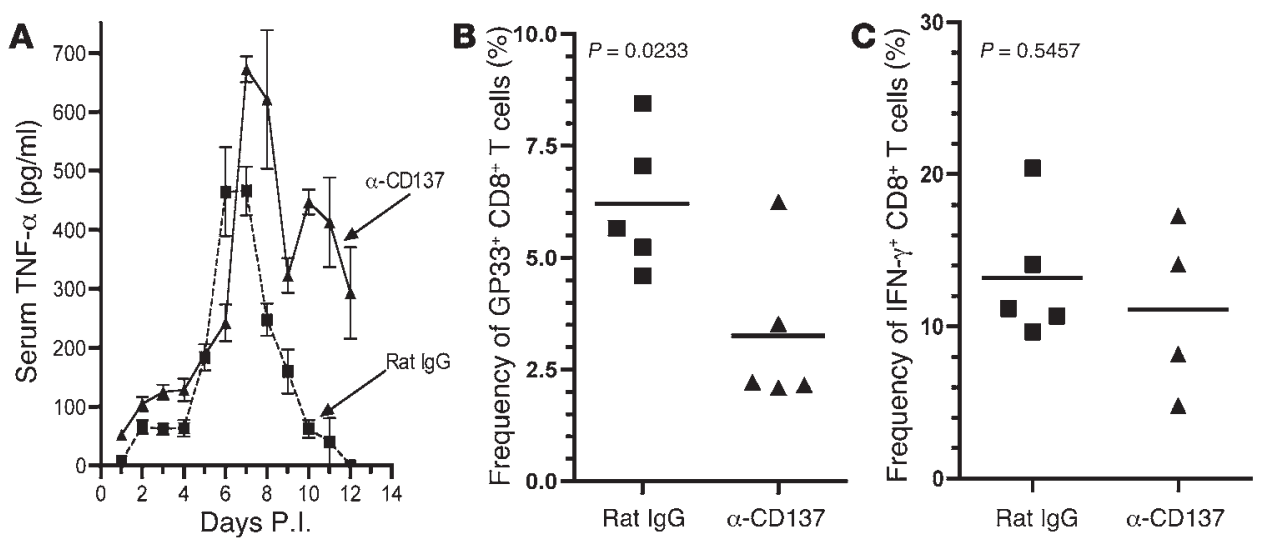

Figure 8

TNF- $\alpha$ and T cell deletion. (A) Serum TNF- $\alpha$ levels were determined in LCMV-infected anti-CD137injected (solid line) or rat IgG-injected (dotted line) mice $(n=5)$ by ELISA. (B) The frequencies of GP33-41 tetramer-positive splenic CD8 ${ }^{+} \mathrm{T}$ cells in LCMV Armstrong-infected C57BL/6 TNF $\alpha^{-1-}$ mice were determined by FACS on day 8 P.I. in mice that had been injected on day 1 P.I. with $200 \mu \mathrm{g}$ of either rat IgG or anti-CD137. (C) Frequencies of IFN- $\gamma^{+}$splenic $\mathrm{CD} 8^{+} \mathrm{T}$ cells from $\mathrm{TNF} \alpha^{-1-}$ mice were determined by FACS on day 8 P.I. in mice that had been injected on day 1 P.I. with $200 \mu \mathrm{g}$ rat IgG or anti-CD137. Lines indicate the mean.

anti-CD137 administration. The overall effect leading to suppression was activation-induced cell death, in which $\mathrm{CD}^{+} \mathrm{T}$ cell deletion was found to be IL-10 dependent. Production of IL-10 was virus- and anti-CD137-dependent during the early stages of infection, and neither infection alone nor anti-CD137 treatment in the absence of infection induced IL-10 production or T cell deletion. In addition, sustained production of TNF- $\alpha$ was observed in day 1 P.I. anti-CD137 injection of LCMV-infected mice but not in virusinfected controls. TNF- $\alpha$ production is a known consequence of LCMV Armstrong infection and occurs during the late stages of infection. Typically TNF- $\alpha$ production is transient and ends within 24-48 hours of onset, as can be seen in Figure 8A. In contrast, mice injected with anti-CD137 1 day P.I. maintained elevated levels of TNF- $\alpha$, resulting in Fas expression on activated T cells, and this in turn led to Fas-mediated T cell apoptosis. This was shown in LCMV-infected anti-CD137 injected mice given neutralizing anti-TNF- $\alpha$. Several important questions concerning the dichotomous behavior of $\mathrm{T}$ cells in response to CD137mediated signals remain. For example, to what extent and for how long is IL-10 or TNF- $\alpha$ produced when anti-CD137 treatment is delayed to the point that it induces costimulation? And what genes are differentially regulated under these conditions? Why would T cells express CD137 so early in the activation process if its signaling induces $\mathrm{T}$ cell deletion? Deletion is not related to specific infectious agents or a particular class of antigen, nor is it dependent on the mode
Table 1

Virus-specific T cell numbers in anti-CD137-treated wild-type and TNF- $\alpha$-deficient mice

\begin{tabular}{|c|c|c|c|c|}
\hline Parameter & $\mathrm{C} 57 \mathrm{BL} / 6+\mathrm{rat} \lg \mathrm{G}$ & $\mathrm{TNF} \alpha^{-1-}+$ rat $\lg \mathrm{G}$ & C57BL/6 + anti-CD137 & $\mathrm{TNF} \alpha^{-/-}+$anti-CD137 \\
\hline \multicolumn{5}{|c|}{ No. total GP33-41 tetramer-positive CD8+ T cells $\left(\times 10^{4}\right)$} \\
\hline Mouse 1 & 100.4 & 139.3 & 0.9 & 10.1 \\
\hline Mouse 2 & 213.3 & 32.4 & 1.7 & 8.6 \\
\hline Mouse 3 & 89.1 & 82.1 & 1.7 & 6.7 \\
\hline Mouse 4 & 50.0 & 247.7 & 2.5 & 56.0 \\
\hline Mean & 79.8 & 125.4 & 1.7 & 20.3 \\
\hline SD & 26.4 & 92.5 & 0.7 & 23.8 \\
\hline \multicolumn{5}{|c|}{ No. total IFN $-\gamma^{+}$CD8 ${ }^{+}$T cells $\left(\times 10^{4}\right)$} \\
\hline Mouse 1 & 127.9 & 483.7 & 1.6 & 11.2 \\
\hline Mouse 2 & 329.5 & 50.3 & 3.3 & 3.3 \\
\hline Mouse 3 & 123.1 & 112.4 & 1.6 & 3.5 \\
\hline Mouse 4 & 58.9 & 435.3 & 2.4 & 100.4 \\
\hline Mean & 159.9 & 270.4 & 2.2 & 29.6 \\
\hline SD & 117.4 & 220.7 & 0.8 & 47.4 \\
\hline
\end{tabular}

of antigen delivery, as we saw the same outcome following i.p. and intranasal infection. We also have yet to discover which cells produce IL-10 and which produce TNF- $\alpha$ and whether this process is facilitated by CD137 signaling directly.

Like LCMV-infected mice, A/PR8/34 influenza-infected mice given a single injection of antiCD137 either fared worse or better than infected controls, depending on the timing of treatment. Mice injected once on day 1 P.I. or thereafter cleared the infection and regained lost weight, and unlike controls, all survived the infection. This observation is in keeping with an earlier study by Bansal-Pakala and Croft, in which they showed that a 2-day delay in treatment with anti-CD137 mAb treatment could overcome $\mathrm{CD}^{+} \mathrm{T}$ cell tolerance to soluble peptide in young mice and enhance $\mathrm{CD} 4^{+} \mathrm{T}$ cell responses in aged mice (31). In contrast, when anti-CD137 was injected day 1 prior to infection, the mice developed progressive and sustained weight loss, and within 12 days of infection $80 \%$ of them had succumbed to infection compared with $40 \%$ of controls. Anti-CD137-injected uninfected mice did not develop any sign of pathology. This study shows that anti-CD137 suppressed 2 dissimilar viral infections. Remarkably, suppression is not observed in tumor-bearing mice. And in SLE and RA mice, anti-CD137-induced immune suppression is not timing restricted $(14,32)$. On the surface this appears to contradict the findings of this report. However, we believe that this is not the case. Although anti-CD137 suppressed T cell-dependent autoimmune responses regardless of when it was given, this was not true when the same mice were immunized with SRBC or human IgG. In these studies, suppression was observed when anti-CD137 was given within 2 days of immunization, just as is shown in our current studies. 


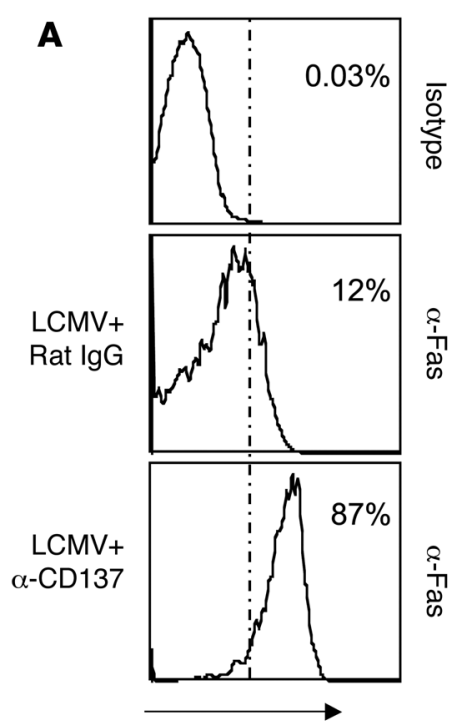

Fas

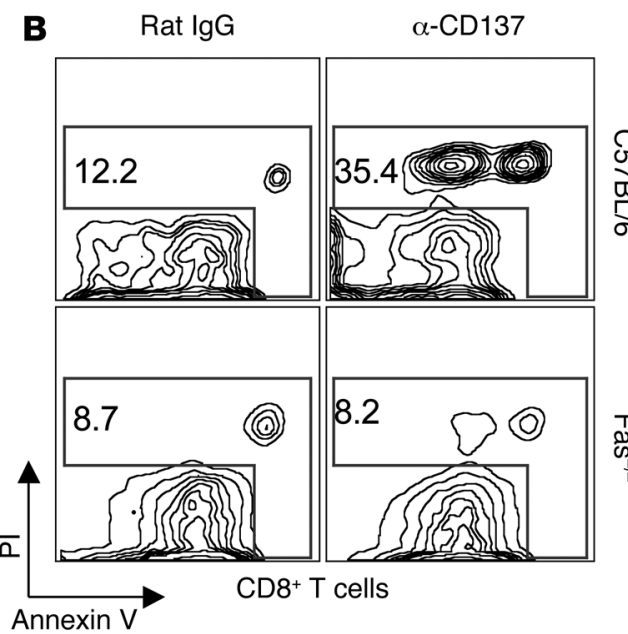

C Rat $\lg G$
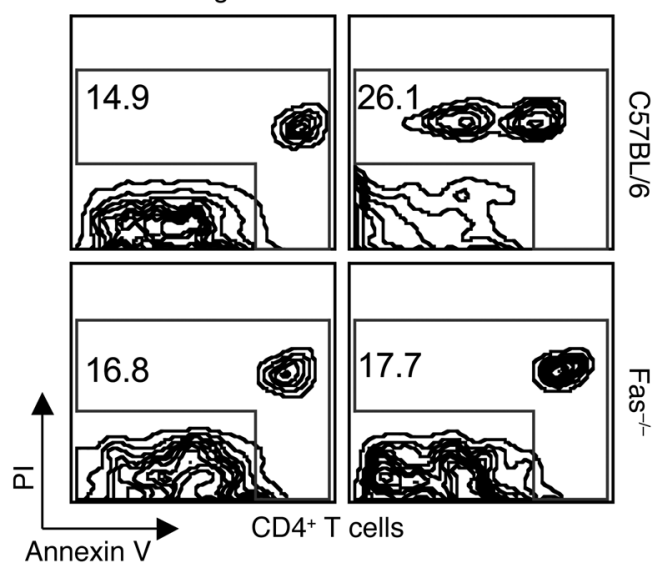

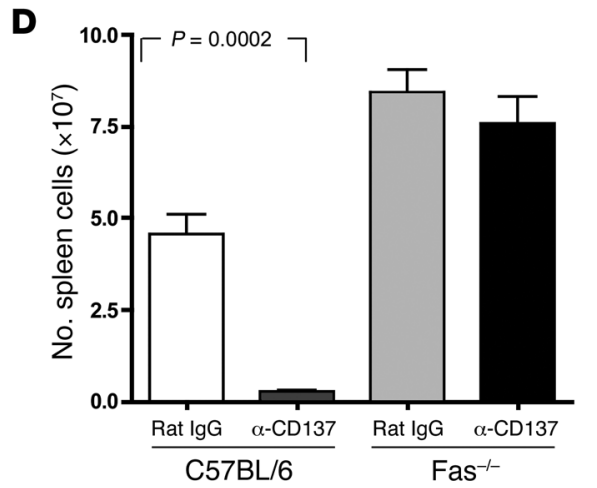

E
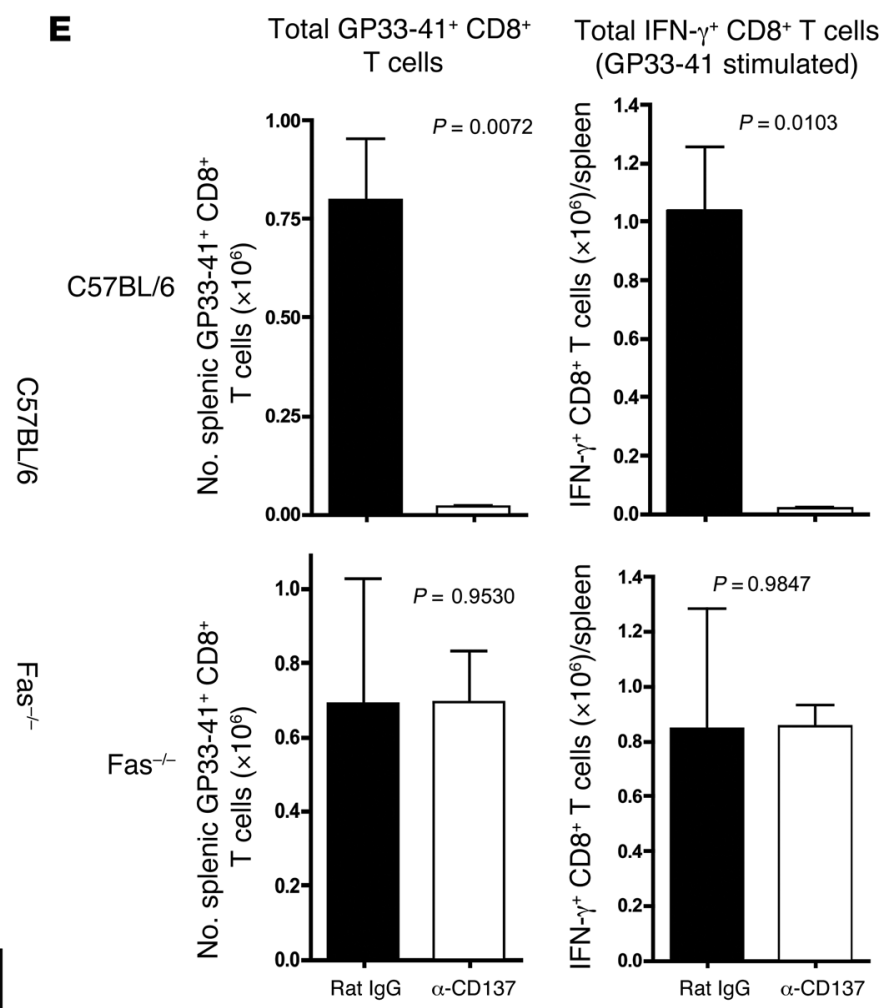

Figure 9

Anti-CD137-mediated T cell deletion is Fas dependent. (A) Anti-CD137 increased Fas expression on CD8 ${ }^{+}$T cells; relative cell numbers are shown. C57BL/6 mice were infected with LCMV and injected with anti-CD137 or rat IgG on day 1 P.I., and on day 8 P.I. splenic CD8 ${ }^{+}$T cells were gated on CD44 ${ }^{\text {hi } C D 62 L ~}{ }^{\text {lo/ }}$ cells and phenotyped for Fas expression. C57BL/6 or Fas-deficient mice were infected with LCMV and injected with anti-CD137 or rat IgG on day 1 P.I. On day 8 P.I. the mice $(n=5)$ were euthanized and the frequency of splenic CD8 ${ }^{+}(\mathbf{B})$ and $C D 4+(C) ~ T$ cells undergoing cell death were measured. Numbers in $\mathbf{B}$ and $\mathbf{C}$ are percentages. PI, propidium iodide. (D) The absolute number of surviving spleen cells was measured. (E) The absolute numbers of GP33-41 tetramer-positive CD8 ${ }^{+} \mathrm{T}$ cells and IFN- $\gamma^{+} \mathrm{CD} 8^{+} \mathrm{T}$ cells following 5 hours of in vitro GP33-41 restimulation are shown. 
C57BL/6
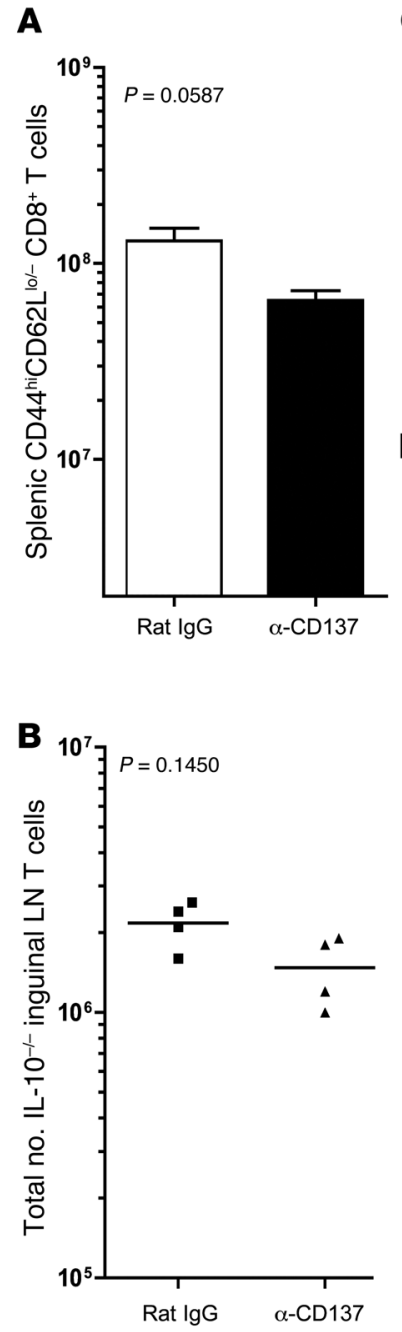

C ${ }^{C D 8}{ }^{+} \mathrm{CD} 44^{\mathrm{r}} \mathrm{CDD} 62 L^{\mathrm{Lo} /}, \mathrm{Fas}$

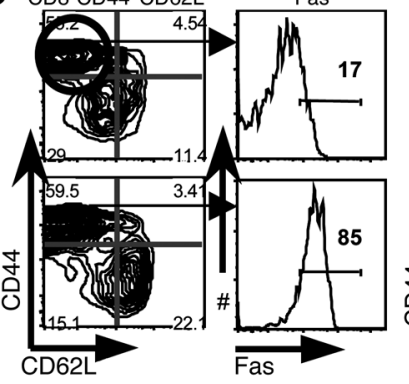

D

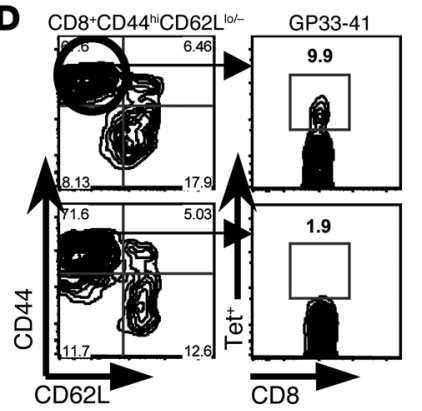

E $\mathrm{CD}^{+} \mathrm{CD} 44^{\mathrm{hi}} \mathrm{CD} 62 \mathrm{Lof}-(\mathrm{GP} 33)-\mathrm{IFN}-\mathrm{y}$

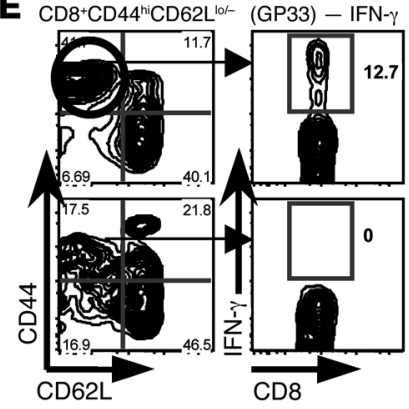

F $\mathrm{CD}^{+} \mathrm{CD} 44^{\mathrm{n}} \mathrm{CD} 62 \mathrm{~L}^{10 /-}(\mathrm{NP} 396)-\mathrm{IFN}-\gamma$

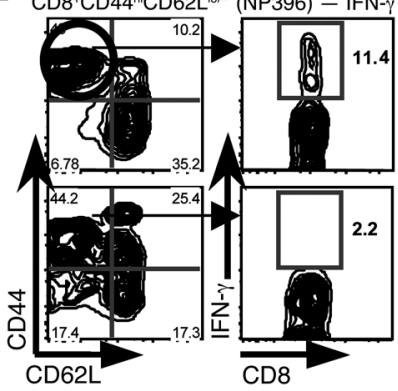

$\mathrm{IL}-10^{-1-}$
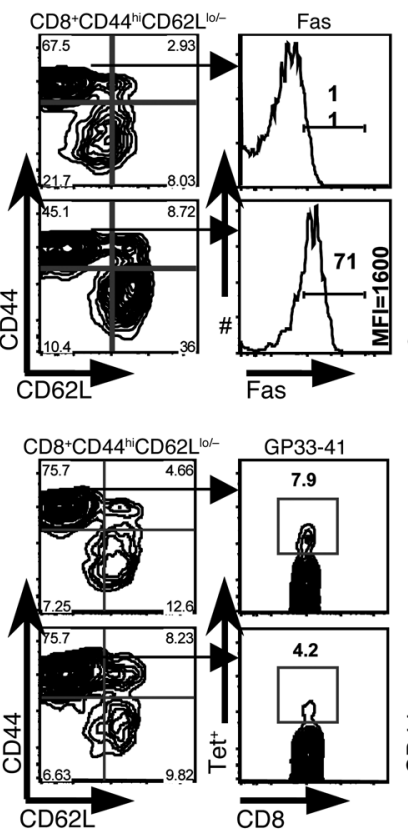

CD8 ${ }^{+} \mathrm{CD} 44^{\mathrm{h}} \mathrm{CD} 62 \mathrm{~L}^{\mathrm{lol}-}(\mathrm{GP} 33)-\mathrm{IFN}-\gamma$

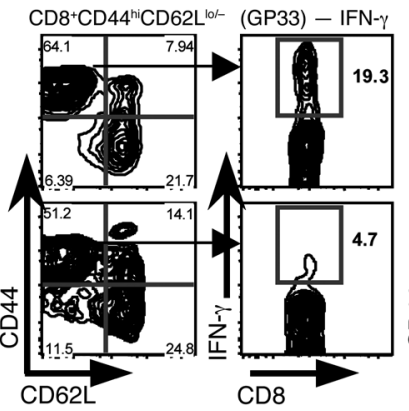

$\mathrm{CD}^{+} \mathrm{CD} 44^{\mathrm{n}} \mathrm{CD} 62 \mathrm{~L}^{\text {lo/ }}$ (NP396) - IFN-

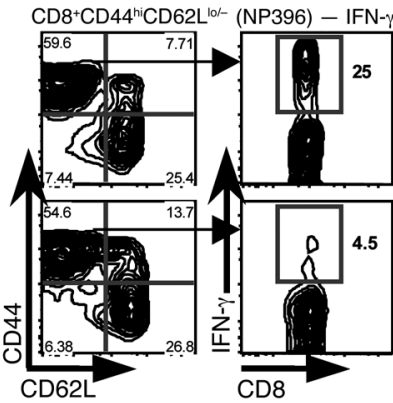

$\mathrm{IL}-10^{-/-}+\alpha-\mathrm{TNF}-\alpha$

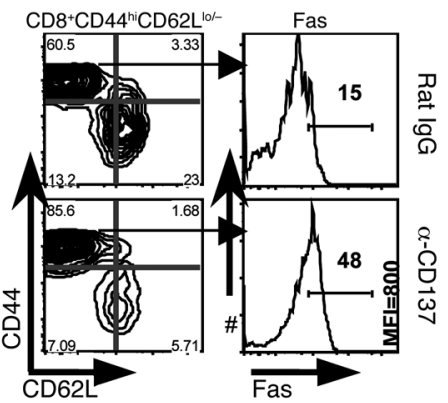

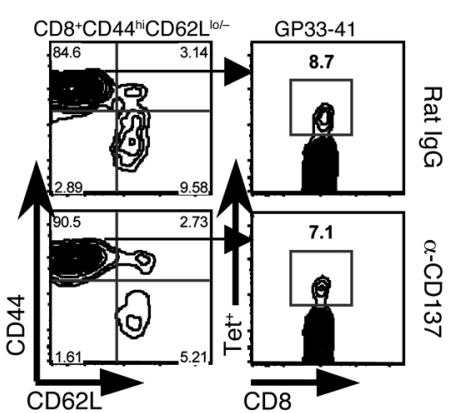
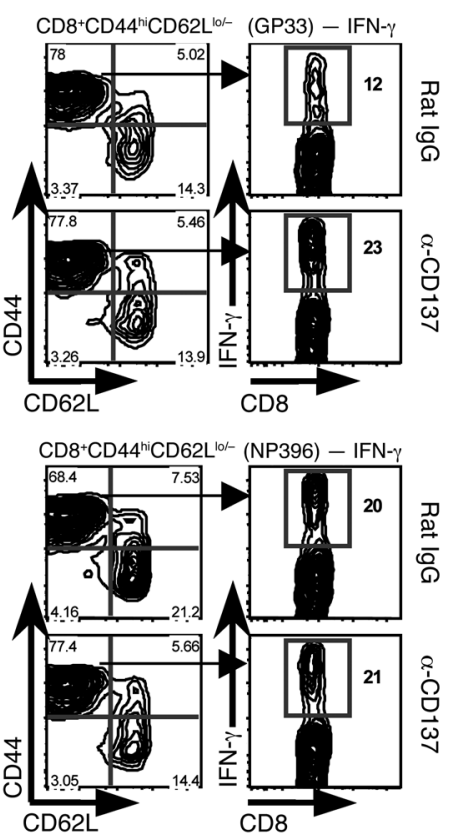

Survival: $\quad 1 / 5 \alpha-C D 137$ day -1

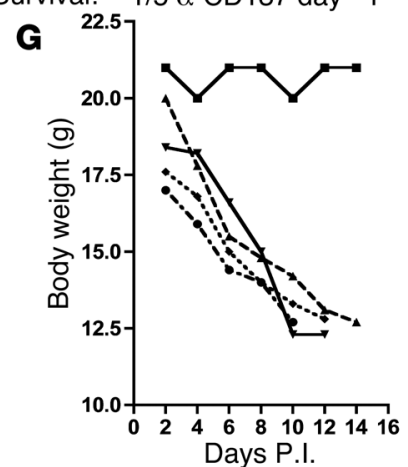

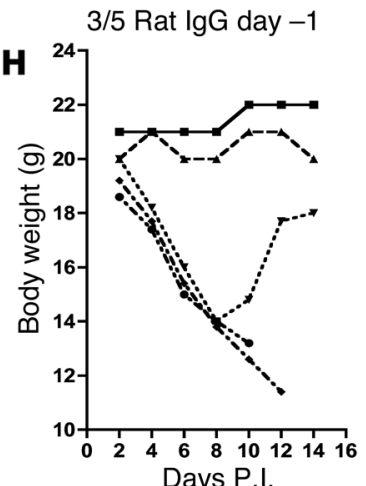

Days P.I.
$5 / 5 \alpha-C D 137$ day +1

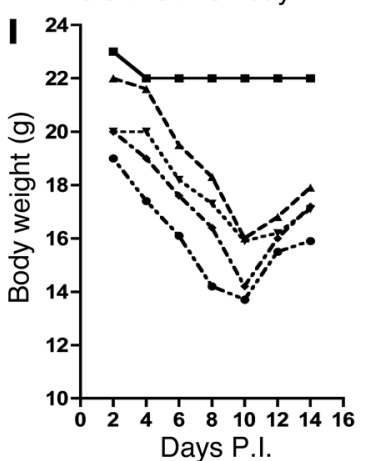




\section{Figure 10}

TNF- $\alpha$-dependent Fas upregulation and its blockade allows for CD8+ T cell survival. Groups of C57BL/6 and C57BL/6 IL10-- mice $(n=5)$ were infected with LCMV and given $200 \mu \mathrm{g}$ of either anti-CD137 or rat IgG day 1 P.I. along with $300 \mu$ n neutralizing anti-TNF- $\alpha$ mAb. (A) LCMV-infected anti-CD137-injected C57BL/6 IL10 ${ }^{-/-}$mice $(n=4)$ were coinjected with $300 \mu \mathrm{g}$ neutralizing anti-TNF- $\alpha \mathrm{mAb}$ on day 8 P.I. The number of CD44 ${ }^{\mathrm{hi}} \mathrm{CD}_{22} \mathrm{~L}^{\mathrm{lo} /-} \mathrm{CD} 8^{+}$splenic T cells was determined by FACS on day 8 P.I. (B) Neutralization of TNF- $\alpha$ prevents the loss of T cells from the LNs of LCMV-infected anti-CD137-injected IL10-/- mice $(n=4)$. Left and right inguinal LNs from each mouse were removed on day 8 P.I. and processed into single-cell suspensions. Viable cells were then counted by hemocytometer, stained with anti-CD3, and analyzed by FACS. (C) On day 8 P.I. activated CD $8^{+}$splenic T cells were phenotyped for the frequency of Fas-expressing cells. (D) In the absence of IL-10 and with the addition of neutralizing anti-TNF- $\alpha$ mAbs, antiviral CD8 ${ }^{+}$ $T$ cell immunity was restored in anti-CD137-injected mice. In the absence of neutralizing anti-TNF- $\alpha \mathrm{mAb}, \mathrm{IL} 10^{-/-}$mice generated a weak GP33-41 tetramer-positive CD8 ${ }^{+} \mathrm{T}$ cell response, whereas in the absence of IL-10 signaling and with the addition of neutralizing anti-TNF- $\alpha$, this response was normal. Tet $^{+}$, Tetramer ${ }^{+}$. IFN- $\gamma$ production by $\mathrm{CD}^{+} \mathrm{T}$ cells from LCMV-infected anti-CD137-injected and anti-TNF- $\alpha$-treated IL $10^{-/-}$mice occurred normally following in vitro GP33-41 peptide restimulation (E) or NP396-404 peptide restimulation $(F)$. Numbers shown in the right-column boxes indicate the percentage $\mathrm{Fas}^{+} \mathrm{CD}^{+} \mathrm{T}$ cells $(\mathbf{C})$, the percentage GP33-41 tetramer ${ }^{+} \mathrm{CD} 8^{+}$ $\mathrm{T}$ cells $(\mathbf{D})$, and the percentage IFN- $\gamma^{+} \mathrm{CD} 8^{+} \mathrm{T}$ cells $(\mathbf{E}$ and $\mathbf{F})$. \#, relative cell number; MFI, mean fluorescence intensity. Anti-CD137-induced immune suppression in influenza-infected mice. C57BL/6 mice were infected with influenza A/PR8/34 by i.n. inoculation and treated with anti-CD137 or rat IgG. Mice were weighed daily and survival monitored. One of 2 experiments is shown. C57BL/6 mice were injected i.v. with $200 \mu \mathrm{g}$ anti-CD137 $(\mathbf{G})$ or rat $\lg G(\mathbf{H})$ on day -1 of infection. The following day the mice were infected with $6 \mathrm{HA}$ units of $\mathrm{A} / \mathrm{PR} 8 / 34$ by i.n. inoculation. (I) C57BL/6 mice were injected with $200 \mu \mathrm{g}$ anti-CD137 on day 1 P.I. as described above. Graphs in G-I show the behavior of 5 mice indicated by lines.

In autoimmune mice $\mathrm{T}$ cell-dependent autoreactive responses are continuously generated due to epitope spreading and/or $\mathrm{T}$ and/or $\mathrm{B}$ cell exhaustion. Under such conditions we would suggest that newly initiated autoreactive responses were being "nipped in the bud" during antigen priming. In this scenario, $\mathrm{T}$ cell exhaustion induced by constant exposure to autoantigens limits the lifespan of these cells that are refractive to anti-CD137. This is not an unreasonable premise, as $\mathrm{T}$ cell exhaustion has been described in mice persistently infected with $\operatorname{LCMV}(33,34)$.

In the case of immune responses to tumor antigens, we find that $\mathrm{CD}^{+} \mathrm{T}$ cell responses, unlike antiviral responses, are not suppressed, but in these situations the mice had been inoculated and tumors allowed to grow prior to anti-CD137 treatment. Thus treatment was not administered during first exposure to antigen. Whether this is an accurate interpretation of why anti-CD137 treatment induces suppression remains to be determined. We do not know why CD137-mediated signals program T cells toward death or whether this process is physiologically relevant. However, it seems that the $\mathrm{T}$ cell is not prepared to receive this early signal through CD137, and this leads to cell death. It is conceivable that anti-CD137 mAbs are inducing activation and at the same time blocking CD137 receptor-ligand interactions necessary for $\mathrm{T}$ cell survival. However, studies in $41 \mathrm{BBL}^{-/-}$mice argue against this interpretation - but this would not hold true if a second, as yet unidentified ligand for CD137 was required for this function.
From DNA microarrays we have found marked changes in $\mathrm{CD}^{+}$ and $\mathrm{CD}^{+} \mathrm{T}$ cell gene expression in LCMV-infected mice given rat IgG or anti-CD137 on day 1 P.I., and these data are currently being evaluated. Regardless of mechanisms involved, the outcomes reported this study might have an important bearing on the development of CD137 ligand-based immunotherapies. An alternative explanation is that anti-CD137 mAbs have a much higher avidity for CD137 than its ligand (4-1BBL). Indeed, the avidity of the $3 \mathrm{H} 3 \mathrm{mAb}$ used in this study is higher than the soluble ligand by 2 orders of magnitude $\left(10^{-11} \mathrm{M}\right.$ versus $10^{-9} \mathrm{M}$, respectively). However, we do not believe this is the case because we have produced a panel of anti-CD137 mAbs having avidities that range from $10^{-9} \mathrm{M}$ to $10^{-12} \mathrm{M}$ and all behave similarly (4-8). Moreover, the avidity of APC-bound 4-1BBL for CD137 is almost certainly greater than the soluble 4-1BBL fusion protein. Perhaps a more likely explanation is that anti-CD137 mAbs induce modulation of key costimulatory receptors from the cell surface, or modulates their signaling activity and these events disturb necessary activation pathways for sustaining early activation and antigen priming. We are currently investigating this possibility.

\section{Methods}

Mice and antibodies. C57BL/6 8- to 12-week-old female mice, C57BL/6 CD45.1 congenic mice, Rag2 $2^{-/}, \mathrm{IL}_{10}^{-/-}, \mathrm{TNF}^{-/-}$, or $\mathrm{Fas}^{-/-}$mice on a C57BL/6 background were purchased from The Jackson Laboratory. C57BL/6 LCMV GP33-41-specific TCR-transgenic Rag-/- mice were purchased from Taconic Farms. C57BL/6 CD137//- mice were generated as previously described (35). Jacques Peschon (Immunex Corp., Seattle, Washington, USA) generously provided 4-1BB ligand ${ }^{-/-}$mice. Mice were housed at the Yerkes National Primate Research Center Vivarium, Emory University. All animal studies reported herein were approved by the Emory University Institutional Animal Care and Use Committee (IACUC). Neutralizing anti-TNF- $\alpha$ mAbs (2E2) were obtained from the NCI Biological Resource Branch, and anti-IL-10R mAbs were produced from the 1-B1-3A hybridoma provided by Drew Pardoll (Johns Hopkins University, Baltimore, Maryland, USA). The $3 \mathrm{H} 3$ clone, a rat $\mathrm{IgG}_{2 \mathrm{a}}$ anti-mouse $\mathrm{CD} 137$ agonistic $\mathrm{mAb}$, and the $9 \mathrm{D} 6$ clone, a rat $\mathrm{IgG}_{2 \mathrm{a}}$ anti-human $\mathrm{CD} 137 \mathrm{mAb}$ were produced as described in refs. 4 and 36 . C57BL/ 6 mice were injected i.p. with $200 \mu \mathrm{g}$ anti-CD137 or rat IgG at various time points as described in Results. Control groups were treated initially with anti-human CD137 $\mathrm{mAb}$ (9D6) and later with rat IgG.

Virus infections. C57BL/ 6 mice were infected i.p. with $2 \times 10^{-5} \mathrm{PFU}$ of the Armstrong CA 1371 strain of LCMV or i.v. with $2 \times 10^{-6} \mathrm{PFU}$ of the clone 13 variant of LCMV (37). Infectious LCMV in serum and tissues was quantitated by plaque assay on Vero cell monolayers, as described previously (38). C57BL/6 mice were infected with $6 \mathrm{HA}$ units of influenza virus strain A/PR8/34/mouse administered i.n. $25 \mu \mathrm{l} /$ naris.

CD8 tetramer and FACS staining. $\mathrm{H}-2 \mathrm{D}^{\mathrm{b}}$ tetramers bound to LCMV peptide GP33-41, NP396-404, NP205-212, GP276-286, or GP92-101 were prepared and used as described previously (23). PBMCs or spleen cells were stained with allophycocyanin-conjugated H-2Db GP33-41 or NP396-404 tetramers, and fluorochrome-conjugated monoclonal anti-mouse CD8 was purchased from BD Pharmingen and analyzed by flow cytometry.

Intracellular staining for IFN- $\gamma$. Intracellular IFN- $\gamma$ staining has been described previously (23). PBMCs or spleen cells were stimulated in vitro with medium, GP33-41, or NP396-404 at $1 \mu \mathrm{g} / \mathrm{ml}$ for 5 hours with Golgiplug (BD Biosciences). Cells were stained with PerCP-conjugated monoclonal anti-CD8 (BD Biosciences) and stained for intracellular IFN- $\gamma$ according to the manufacturer's recommended protocol. FITC-conjugated or allophycocyanin-conjugated monoclonal rat anti-mouse IFN- $\gamma$ and control isotype $\mathrm{Ab}$ ( rat $\operatorname{IgG}_{1}$ ) from BD Biosciences were used for intracellular IFN- $\gamma$ staining. 
CTL assays. MHC class I-restricted LCMV-specific CTL activity was determined ex vivo by ${ }^{51} \mathrm{Cr}$ release assay as previously described (38). MC57 target cells were either infected with LCMV or preincubated for 30 minutes with individual viral peptides as indicated in the legend for Figure $1(10 \mu \mathrm{g} / \mathrm{ml})$.

ELISA measurements. Sera were collected as indicated in the legends for Figures 1, 7, and 8. Lysates of LCMV-infected or uninfected BHK-21 cells were generated and bound to microtiter plates overnight at $4{ }^{\circ} \mathrm{C}$. Plates were washed 3 times with PBS plus $0.5 \%$ FBS and $0.5 \%$ Triton X-100. Serum from preimmune or immune mice with or without anti-CD137 treatment was allowed to bind for 90 minutes at room temperature. Bound LCMVspecific IgG was detected with HRP-conjugated goat $\alpha$-mouse IgG and visualized by HRP substrate (R\&D Systems) as described previously (39). Serum cytokine measurements were performed using ELISA kits from BioLegend following the manufacturer's instructions.

Anti-TNF- $\alpha$ treatment of IL-10-deficient mice. IL-10-/- mice were infected with LCMV at day 0 and injected on day 1 P.I. with $200 \mu \mathrm{g}$ rat IgG or antiCD137 plus $300 \mu \mathrm{g}$ anti-TNF- $\alpha$. On day 8 P.I. the mice were sacrificed and splenocytes were stained with fluorochrome-conjugated $\mathrm{mAbs}$ to $\mathrm{T}$ cell antigens, CD95 (Fas), and MHC class I tetramers containing the LCMV-specific peptide GP33-41. Cells were permeabilized and intracellularly stained with allophycocyanin-conjugated anti-IFN- $\gamma \mathrm{mAb}$ after restimulation with LCMV-specific GP33-41 or NP396-404 peptides for 5 hours at $37^{\circ} \mathrm{C}$.

Flow cytometry and data processing. PBMCs, and spleen and lymph node cells were isolated and blocked with $10 \mu \mathrm{g} / \mathrm{ml}$ anti-CD16/anti-CD32 (clone 2.4G2; ATCC) for 10 minutes in PBS supplemented with $1.5 \%$ BSA and $0.05 \%$ sodium azide. FACS analysis was carried out on a BD FACSCalibur or LSRII multiparameter flow cytometer (BD Biosciences). Aliquots of cells $\left(10^{6}\right)$ were suspended in $0.1 \mathrm{ml}$ BD FACS buffer and incubated on ice for 20 minutes with FITC-, PE-, PerCP-, and allophycocyanin-conjugated mAbs. Cells were washed and resuspended in $200 \mu \mathrm{l}$ PBS containing $1 \%$ paraformaldehyde prior to FACS acquisition. Lymphocytes were stained with the following mAbs: anti-CD3, anti-CD4, anti-CD8, antiCD43, anti-CD44, anti-CD62L, anti-CD11c, anti-CD11b, and anti-Fas (BD - Pharmingen). Expression of CD137 or 4-1BB ligand was measured with the anti-CD137 mAb (clone 3H3) or anti-4-1BB ligand (clone 19H3.1) conjugated to FITC. Annexin V and 7AAD (or propidium iodide) staining was performed according to the manufacturer's protocol (Invitrogen). Data analysis was carried using FlowJo software (TreeStar Inc.).

Adoptive T cell transfer. C57BL/6, C57BL/6 CD137-/-, P14, and SMARTA spleen cells were negatively selected with a cocktail of mAb-coated magnetic beads to enrich the $\mathrm{T}$ cell populations (Miltenyi Biotec). MACS-purified T cells $\left(4-20 \times 10^{6}\right)$ with greater than $95 \%$ purity were injected into $\mathrm{C} 57 \mathrm{BL} / 6 \mathrm{Rag}^{-1-}$ mice. In some experiments $\mathrm{T}$ cells were labeled with $2.5 \mu \mathrm{M}$ CFSE for 10 minutes at $37^{\circ} \mathrm{C}$ prior to adoptive transfer. Mice were infected with LCMV Armstrong the following day and injected with anti-CD137 or rat IgG on day 1 P.I. as described. At the indicated times (see the legends for Figures 3 and 6) spleens were harvested and CFSE dilution or LCMV tetramer binding and IFN- $\gamma$ production were determined.

Statistics. A 2-tailed Student's $t$ test was used. A $P$ value of less than 0.05 was considered significant.

\section{Acknowledgments}

This work was supported by NIH grants RO1 CA85860 and R01 AI0592 (to R.S. Mittler), RO1 AI52108 (to A.T. Vella), and RO1 EY13325 (to B.S. Kwon); by the Cancer Research Institute (to C.H. Maris); and by the SRC Fund from KISEF and Korean MOST (to B.S. Kwon).

Received for publication April 17, 2007, and accepted in revised form June 27, 2007.

Address correspondence to: Robert S. Mittler, Emory Vaccine Center, Emory University School of Medicine, 954 Gatewood Rd. NE, Atlanta, Georgia 30329, USA. Phone: (404) 727-9425; Fax: (404) 727-8199; E-mail: rmittler@rmy.emory.edu.

Charles H. Maris's present address is: Sidney Kimmel Comprehensive Cancer Center, Johns Hopkins University, Baltimore, Maryland, USA.

Benyue Zhang, Charles H. Maris, and Juergen Foell contributed equally to this work.
1. Kwon, B.S., and Weissman, S.M. 1989. cDNA sequences of two inducible T-cell genes. Proc. Natl. Acad. Sci. U. S. A. 86:1963-1967.

2. Pollok, K.E., et al. 1993. Inducible T cell antigen 4-1BB. Analysis of expression and function. J. Immunol. 150:771-781.

3. Watts, T.H. 2005. TNF/TNFR family members in costimulation of T cell responses. Annu. Rev. Immunol. 23:23-68.

4. Shuford, W.W., et al. 1997. 4-1BB costimulatory signals preferentially induce CD8 $+\mathrm{T}$ cell proliferation and lead to the amplification in vivo of cytotoxic $T$ cell responses. J. Exp. Med. 186:47-55.

5. Gramaglia, I., et al. 2000. Co-stimulation of antigen-specific CD4 T cells by 4-1BB ligand. Eur. J. Immunol. 30:392-402.

6. Cannons, J.L., et al. 2001. 4-1BB ligand induces cell division, sustains survival, and enhances effector function of CD4 and CD8 T cells with similar efficacy. J. Immunol. 167:1313-1324.

7. Goodwin, R.G., et al. 1993. Molecular cloning of a ligand for the inducible $\mathrm{T}$ cell gene 4-1BB: a member of an emerging family of cytokines with homology to tumor necrosis factor. Eur. J. Immunol. 23:2631-2641.

8. Takahashi, C., Mittler, R.S., and Vella, A.T. 1999. Cutting edge: $4-1 \mathrm{BB}$ is a bona fide CD8 T cell survival signal. J. Immunol. 162:5037-5040.

9. Melero, I., et al. 1997. Monoclonal antibodies against the 4-1BB T-cell activation molecule eradicate established tumors. Nat. Med. 3:682-685.
10. Wilcox, R.A., et al. 2002. Provision of antigen and CD137 signaling breaks immunological ignorance, promoting regression of poorly immunogenic tumors. J. Clin. Invest. 109:651-659. doi:10.1172/ JCI200214184.

11. Mittler, R.S., et al. 1999. Anti-4-1BB monoclonal antibodies abrogate $\mathrm{T}$ cell-dependent humoral immune responses in vivo through the induction of helper T cell anergy. J. Exp. Med. 190:1535-1540.

12. Harrison, J.M., et al. 2006. 4-1BBL coexpression enhances HIV-specific CD8 T cell memory in a poxvirus prime-boost vaccine. Vaccine. 24:6867-6874.

13. Wu, Z.Q., et al. 2003. 4-1BB (CD137) differentially regulates murine in vivo protein- and polysaccharidespecific immunoglobulin isotype responses to Streptococcus pneumoniae. Infect. Immun. 71:196-204.

14. Foell, J., et al. 2003. CD137 costimulatory T cell receptor engagement reverses acute disease in lupus-prone $\mathrm{NZB} \times \mathrm{NZW} \mathrm{F}_{1}$ mice. J. Clin. Invest. 111:1505-1518. doi:10.1172/JCI200317662.

15. Sun, Y., et al. 2002. Costimulatory molecule-targeted antibody therapy of a spontaneous autoimmune disease. Nat. Med. 8:1405-1413.

16. Niu, L., et al. 2007. Cytokine-mediated disruption of lymphocyte trafficking, hemopoiesis, and induction of lymphopenia, anemia, and thrombocytopenia in anti-CD137-treated mice. J. Immunol. 178:4194-4213.

17. Kolumam, G.A., Thomas, S., Thompson, L.J., Sprent, J., and Murali-Krishna, K. 2005. Type I inter- ferons act directly on CD8 T cells to allow clonal expansion and memory formation in response to viral infection. J. Exp. Med. 202:637-650.

18. Pestka, S., et al. 2004. Interleukin-10 and related cytokines and receptors. Annu. Rev. Immunol. 22:929-979.

19. Brooks, D.G., et al. 2006. Interleukin-10 determines viral clearance or persistence in vivo. Nat. Med. 12:1301-1309.

20. Ejrnaes, M., et al. 2006. Resolution of a chronic viral infection after interleukin-10 receptor blockade. J. Exp. Med. 203:2461-2472.

21. Castro, A.G., et al. 2000. Anti-interleukin 10 receptor monoclonal antibody is an adjuvant for $\mathrm{T}$ helper cell type 1 responses to soluble antigen only in the presence of lipopolysaccharide. J. Exp. Med. 192:1529-1534

22. Ayala, A., Chung, C.S., Song, G.Y., and Chaudry, I.H. 2001. IL-10 mediation of activation-induced TH1 cell apoptosis and lymphoid dysfunction in polymicrobial sepsis. Cytokine. 14:37-48.

23. Murali-Krishna, K., et al. 1998. Counting antigenspecific CD8 T cells: a reevaluation of bystander activation during viral infection. Immunity. 8:177-187.

24. Badovinac, V.P., Corbin, G.A., and Harty, J.T. 2000. Cutting edge: OFF cycling of TNF production by antigen-specific CD8+ T cells is antigen independent. J. Immunol. 165:5387-5391.

25. Beg, A.A., and Baltimore, D. 1996. An essential role for NF-kappaB in preventing TNF-alpha-induced 
cell death. Science. 274:782-784.

26. Van Antwerp, D.J., et al. 1996. Suppression of TNF-alpha-induced apoptosis by NF-kappaB. Science. 274:787-789.

27. Oyaizu, N., et al. 1994. Cross-linking of CD4 molecules upregulates Fas antigen expression in lymphocytes by inducing interferon-gamma and tumor necrosis factor-alpha secretion. Blood. 84:2622-2631.

28. Weller, M., et al. 1994. Anti-Fas/APO-1 antibodymediated apoptosis of cultured human glioma cells. Induction and modulation of sensitivity by cytokines. J. Clin. Invest. 94:954-964.

29. Takahashi, C., Mittler, R.S., and Vella, A.T. 2001. Differential clonal expansion of CD4 and CD8 T cells in response to 4-1BB ligation: contribution of 4-1BB during inflammatory responses. Immunol. Lett. 76:183-191.

30. Seo, S.K., et al. 2004. 4-1BB-mediated immunothera- py of rheumatoid arthritis. Nat. Med. 10:1088-1094. 31. Bansal-Pakala, P., and Croft, M. 2002. Defective T cell priming associated with aging can be rescued by signaling through 4-1BB (CD137). J. Immunol. 169:5005-5009.

32. Foell, J.L., et al. 2004. Engagement of the CD137 (4-1BB) costimulatory molecule inhibits and reverses the autoimmune process in collageninduced arthritis and establishes lasting disease resistance. Immunology. 113:89-98.

33. Zajac, A.J., et al. 1998. Viral immune evasion due to persistence of activated $\mathrm{T}$ cells without effector function. J. Exp. Med. 188:2205-2213.

34. Moskophidis, D., Lechner, F., Hengartner, H., and Zinkernagel, R.M. 1994. MHC class I and nonMHC-linked capacity for generating an anti-viral CTL response determines susceptibility to CTL exhaustion and establishment of virus persistence in mice. J. Immunol. 152:4976-4983.

35. Kwon, B.S., et al. 2002. Immune responses in 4-1BB (CD137)-deficient mice. J. Immunol. 168:5483-5490.

36. Loo, D.T., et al. 1997. Analysis of 4-1BBL and laminin binding to murine $4-1 \mathrm{BB}$, a member of the tumor necrosis factor receptor superfamily, and comparison with human 4-1BB. J. Biol. Chem. 272:6448-6456.

37. Ahmed, R., et al. 1984. Selection of genetic variants of lymphocytic choriomeningitis virus in spleens of persistently infected mice. Role in suppression of cytotoxic T lymphocyte response and viral persistence. J. Exp. Med. 160:521-540.

38. Maris, C.H., Miller, J.D., Altman, J.D., and Jacob, J. 2003. A transgenic mouse model genetically tags all activated CD8 T cells. J. Immunol. 171:2393-2401.

39. Slifka, M.K., and Ahmed, R. 1996. Limiting dilution analysis of virus-specific memory B cells by an ELISPOT assay. J. Immunol. Methods. 199:37-46. 